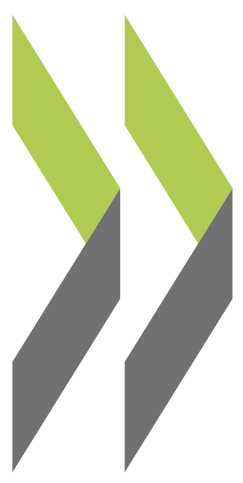

OECD Economics Department Working Papers No. 1131

\title{
Overcoming Vulnerability of Unemployment Insurance Schemes
} Jon Pareliussen 
Organisation de Coopération et de Développement Économiques

Organisation for Economic Co-operation and Development

03-Jul-2014

ECONOMICS DEPARTMENT

English - Or. English

\section{OVERCOMING VULNERABILITIES OF UNEMPLOYMENT INSURANCE SCHEMES}

ECONOMICS DEPARTMENT WORKING PAPERS No. 1131

\section{By Jon Pareliussen}

OECD Working Papers should not be reported as representing the official views of the OECD or of its member countries. The opinions expressed and arguments employed are those of the author(s).

Authorised for publication by Jean-Luc Schneider, Deputy Director, Policy Studies Branch, Economics Department.

All Economics Department Working Papers are available through OECD's Internet website at http://www.oecd.org/eco/workingpapers

JT03360114

Complete document available on OLIS in its original format

This document and any map included herein are without prejudice to the status of or sovereignty over any territory, to the delimitation of international frontiers and boundaries and to the name of any territory, city or area. 
OECD Working Papers should not be reported as representing the official views of the OECD or of its member countries. The opinions expressed and arguments employed are those of the author(s).

Working Papers describe preliminary results or research in progress by the author(s) and are published to stimulate discussion on a broad range of issues on which the OECD works.

Comments on Working Papers are welcomed, and may be sent to the Economics Department, OECD, 2 rue André-Pascal, 75775 Paris Cedex 16, France, or by e-mail to eco.contact@oecd.org.

This document and any map included herein are without prejudice to the status of or sovereignty over any territory, to the delimitation of international frontiers and boundaries and to the name of any territory, city or area.

The statistical data for Israel are supplied by and under the responsibility of the relevant Israeli authorities. The use of such data by the OECD is without prejudice to the status of the Golan Heights, East Jerusalem and Israeli settlements in the West Bank under the terms of international law.

\section{(c) OECD (2014)}

You can copy, download or print OECD content for your own use, and you can include excerpts from OECD publications, databases and multimedia products in your own documents, presentations, blogs, websites and teaching materials, provided that suitable acknowledgment of OECD as source and copyright owner is given. All requests for commercial use and translation rights should be submitted to rights@oecd.org 


\section{ABSTRACT / RÉSUMÉ \\ Overcoming vulnerability of unemployment insurance schemes}

Unemployment insurance is a key tool for risk sharing and redistribution and also a prominent automatic stabiliser. It is a volatile spending item by design, which can lead to vulnerabilities. This paper explores various shocks and sources of vulnerability of the unemployment insurance schemes of OECD and BRIICS countries. Policies that boost both financial resilience and benefit adequacy as well as policy trade-offs are explored. Four country clusters are identified with key similarities in the overall policy mix that can shed light on why some countries boast generous benefits and at the same time display high economic efficiency, while other countries face a much more pronounced trade-off.

JEL classification codes: J21; J40; J65; J68

Keywords: Unemployment insurance, unemployment, employment services, labour market policy

$* * * * *$

\section{Surmonter les vulnérabilités des systèmes d'assurance chômage}

L'assurance chômage est un instrument clé de mutualisation des risques et de redistribution, et c'est aussi un stabilisateur automatique majeur. C'est, fondamentalement, un poste de dépenses volatile, ce qui peut entraîner des vulnérabilités. Ce document examine divers chocs et sources de vulnérabilité pour les systèmes d'assurance chômage des pays de l'OCDE et pays BRIICS. Les politiques de nature à améliorer à la fois la résilience financière et le caractère suffisant des prestations, ainsi que les choix à opérer, y sont examinés. Quatre groupes de pays présentant d'importantes similitudes de par l'éventail des politiques mises en œuvre y sont identifiés, ce qui permet de mieux comprendre pourquoi certains pays enregistrent à la fois des prestations généreuses et de faibles inégalités de revenu en même temps qu'un haut niveau d'efficience économique, tandis que, dans d'autres, ces situations apparaissent beaucoup plus difficiles à concilier.

Classification JEL : J21 ; J40 ; J65 ; J68

Mots clés : assurance chômage, chômage, services de l'emploi, politiques du marché du travail 


\section{TABLE OF CONTENTS}

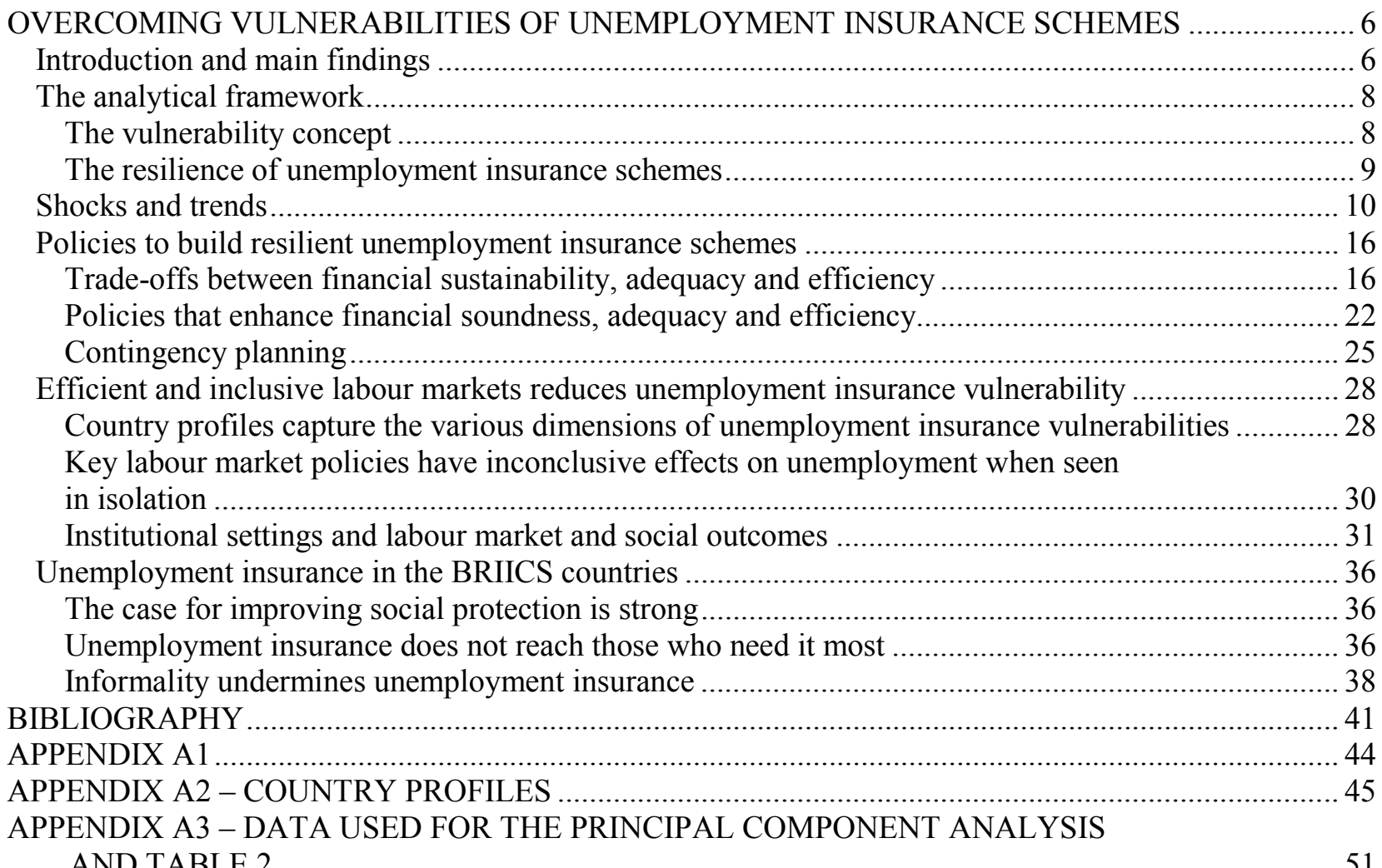

\section{Tables}

1. Net replacement rates and duration 20

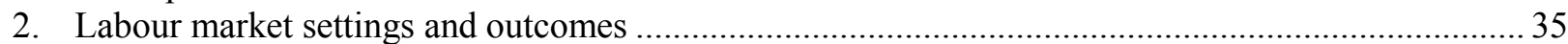

\section{Figures}

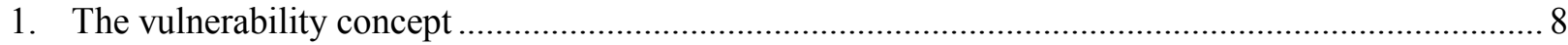

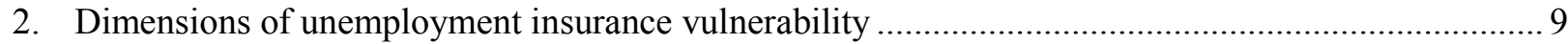

3. Unemployment and ALMP spending before and during the initial phase of the crisis ..................... 11

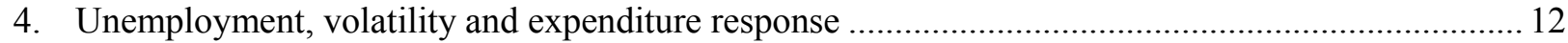

5. Vulnerability of unemployment insurance schemes to GDP shocks .......................................... 14

6. Unemployment rates are often higher among immigrants than natives ......................................... 15

7. Youth poverty has soared during the crisis, while older people were better protected .................... 17

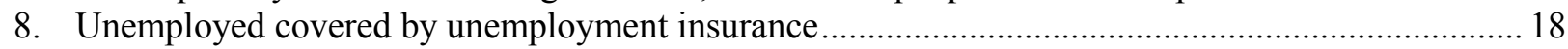

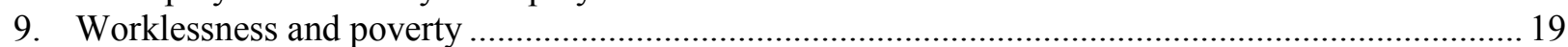

10. Decomposition of GDP losses during the initial phase of the recession ......................................... 21

11. The responsiveness of active labour market policies to unemployment..........................................22

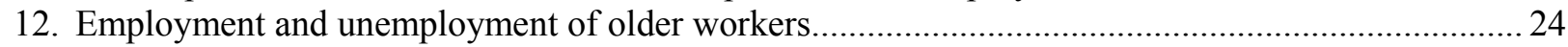

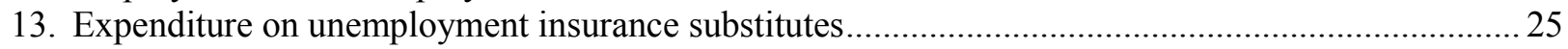

14. ALMP spending on training was cut back in several crisis countries ............................................. 28

15. Unemployment insurance indicators for Denmark and the United States.......................................29

16. Labour market settings - factor composition ................................................................................... 33 


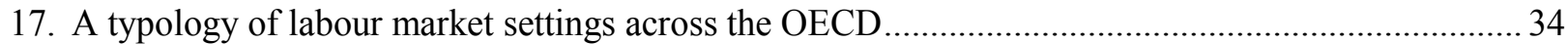

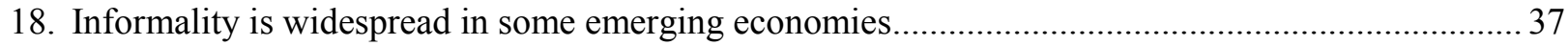

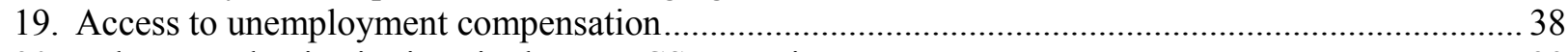

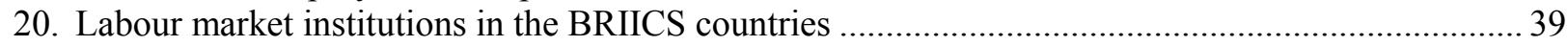

\section{Boxes}

1. GDP shocks can lead to an upward creep in unemployment insurance spending ............................ 13

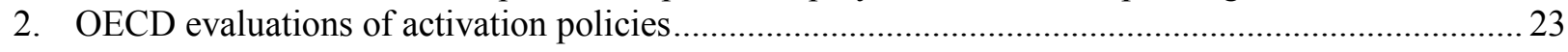

3. Country profiles of unemployment insurance: The case of Denmark

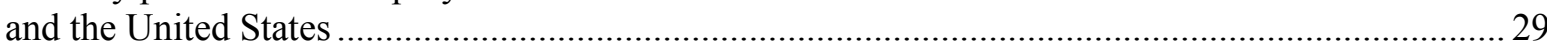




\title{
OVERCOMING VULNERABILITIES OF UNEMPLOYMENT INSURANCE SCHEMES
}

\author{
by \\ Jon Pareliussen ${ }^{1}$
}

\begin{abstract}
"The real grievance of the worker is the insecurity of his existence; he is not sure that he will always have work, he is not sure that he will always be healthy, and he foresees that he will one day be old and unfit to work. If he falls into poverty, even if only through a prolonged illness, he is then completely helpless, left to his own devices, and society does not currently recognize any real obligation towards him beyond the usual help for the poor, even if he has been working all the time ever so faithfully and diligently."
\end{abstract}

Otto von Bismarck, 20 March 1884 (Hollyday, 1970)

\section{Introduction and main findings}

1. The labour market performance of the OECD and BRIICS countries before and during this crisis has been uneven, with some countries doing much better than others. Some countries showed generous unemployment benefits combined with low unemployment, high output and relatively strong resilience to the recent crisis on all these counts. Other countries have had to face soaring unemployment and unemployment benefits, even though unemployment benefits are less generous and fewer are entitled to them, which has implied a serious drag on public finances. This paper seeks to shed light on how unemployment insurance schemes can be made more resilient to shocks without sacrificing the income security of the individuals who lose their job. Many of the issues discussed in this paper apply also to means-tested unemployment support, and such support is also included in some of the indicators presented in the paper.

2. The main findings are:

- Unemployment insurance shelters individuals from the full effects of adverse macroeconomic shocks through risk sharing and play a useful role as automatic stabiliser. An additional purpose of unemployment insurance is redistribution across individuals.

- An unemployment insurance system is resilient, if even during deep recessions the system remains financially sound, gives adequate income support to the unemployed and supports

1. The author is member of the Economics Department of the OECD. He thanks Jørgen Elmeskov, Jean-Luc Schneider, Paul Swaim, Alexander Hijzen, Herwig Immervoll, Peter Hoeller, Falilou Fall and Mauro Pisu for comments on earlier drafts, Debbie Bloch for statistical support and Celia Rutkoski for assistance in preparing the document. 
overall demand; and supports, or does not unnecessarily hamper return to work, labour market flexibility and productivity growth.

- As a prominent automatic stabiliser, unemployment insurance is supposed to be a volatile spending item. If the central government has a sound fiscal position and explicitly guarantees the unemployment insurance scheme fully, the unemployment scheme is by definition financially sustainable in the short term. In countries where these two conditions do not hold, the vulnerability of the scheme is higher the higher the volatility of unemployment insurance expenditure.

- Spending volatility does not only depend on the volatility of unemployment, but also how unemployment fluctuations translate into higher expenditure, as well as long-term trends in equilibrium unemployment caused by factors such as demographic and immigration trends and asymmetric policy response to economic fluctuations.

- When adverse shocks hit the economy, the settings of the unemployment insurance schemes can lead to policy trade-offs. Generous benefits, long duration and high coverage generate large spending spikes during a downturn, and can create disincentives to work. Spending can be contained directly by adjusting replacement rates, duration and eligibility criteria. Stringent eligibility criteria, very short duration, low benefits and other factors can, however, reduce the coverage and adequacy of unemployment insurance to such an extent that it will not perform its core functions as a risk sharing and redistribution tool and as an automatic stabiliser.

- Contingency plans should be in place to better cope with large unemployment shocks. Temporary extensions of unemployment benefit duration and temporary loosening of eligibility criteria may have a useful role to play in countries where duration is low and access to social assistance is limited. Activation policies should be scaled up during crises.

- This tension between financial sustainability and efficiency on the one hand and adequate income support on the other can be eased by careful design and efficient flanking policies. Effective and adequately funded activation policies with job search conditionality as the core underpin financial soundness with little sacrifice for adequacy and macroeconomic stability. Other policies that improve the functioning of labour and product markets can also ease the trade-off by reducing unemployment, increasing employment and expanding the tax base.

- Good labour market policy settings reduce the vulnerability of unemployment insurance schemes to adverse shocks. Clustering countries against their labour market policy settings shows that the cluster including the Nordic and English-speaking countries achieves both financial soundness and a good labour market performance. On the other hand, the social safety net in much stronger in the Nordic than English-speaking countries. The financial soundness and labour market performance of a group of mainly continental and southern European as well as Eastern European countries is inferior. The strength of the social safety nets in continental and southern European cluster lies between that of the Nordic and English-speaking countries, while Eastern European countries also have relatively weak safety nets.

- The existence of widespread poverty, informal work and weak governance structures in the BRIICS countries need to be addressed. Policies should be designed to increase formality, increase social insurance coverage and ensure that there is a safety net for the poorest individuals, since liquidity constraints lead to excessive risk aversion. 
3. The second section of this paper provides the analytical framework for the analysis of vulnerabilities of social institutions. Section 3 reviews the various shocks that are relevant for unemployment insurance schemes. Section 4 addresses trade-offs and complementarities between the goals of financial resilience, adequacy and efficiency in the design of unemployment insurance. In Section 5 country profiles are presented, and flanking policies that affect the resilience of unemployment insurance schemes are investigated. Section 6 reviews issues arising from widespread informal work and weak governance structures in the BRIICS economies.

\section{The analytical framework}

\section{The vulnerability concept}

4. The vulnerability of an institution is defined as the risk that the institution becomes unable to absorb and cope with a negative shock, which could lead to poorer than expected outcomes or to the breaking of institutional promises, like for example a lowering of the unemployment insurance replacement rate. Vulnerability can be analysed along three dimensions: i) the adverse shocks social institutions face; ii) the institutional capacity to absorb, cope with and recover from shocks; iii) the resulting effect on outcomes or promises of social institutions. The vulnerability of outcomes will depend on the nature and magnitude of the shocks as well as the resilience - i.e. the ability to recover from shocks - of the institution (Figure 1).

Figure 1. The vulnerability concept

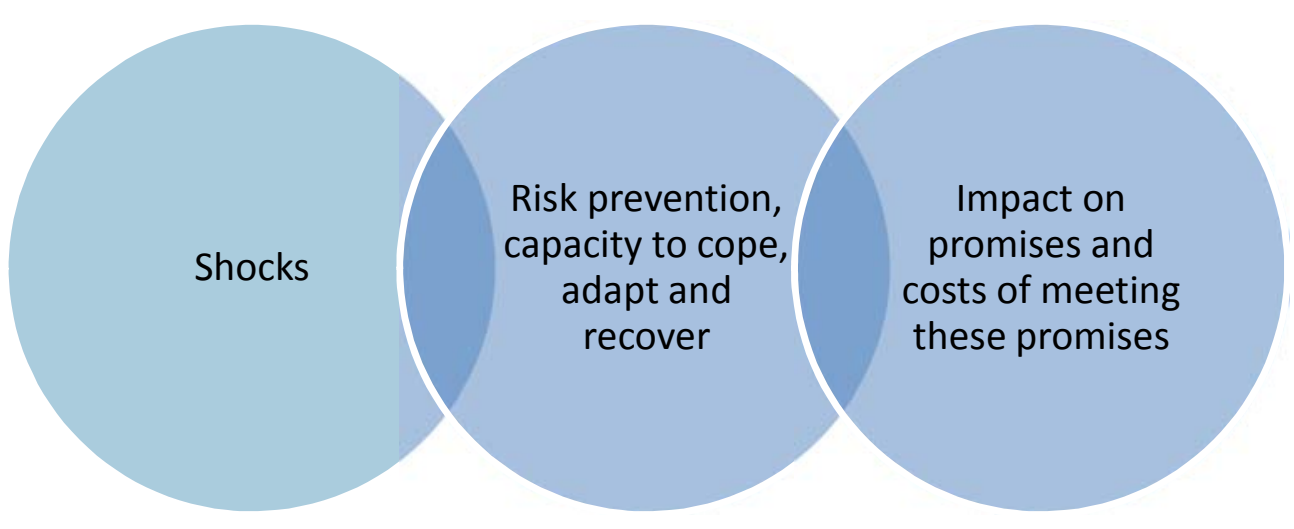

5. Within this framework different types of vulnerabilities can be analysed (Figure 2). Financial vulnerability can lead to the risk that institutional promises will be broken in the face of a heavy adverse shock. The lack of adequacy is a functional vulnerability where the generosity and/or coverage of a social institution are insufficient in terms of risk sharing, macroeconomic stability, support to return to selfsufficiency and preserving the dignity of individuals. 
Figure 2. Dimensions of unemployment insurance vulnerability

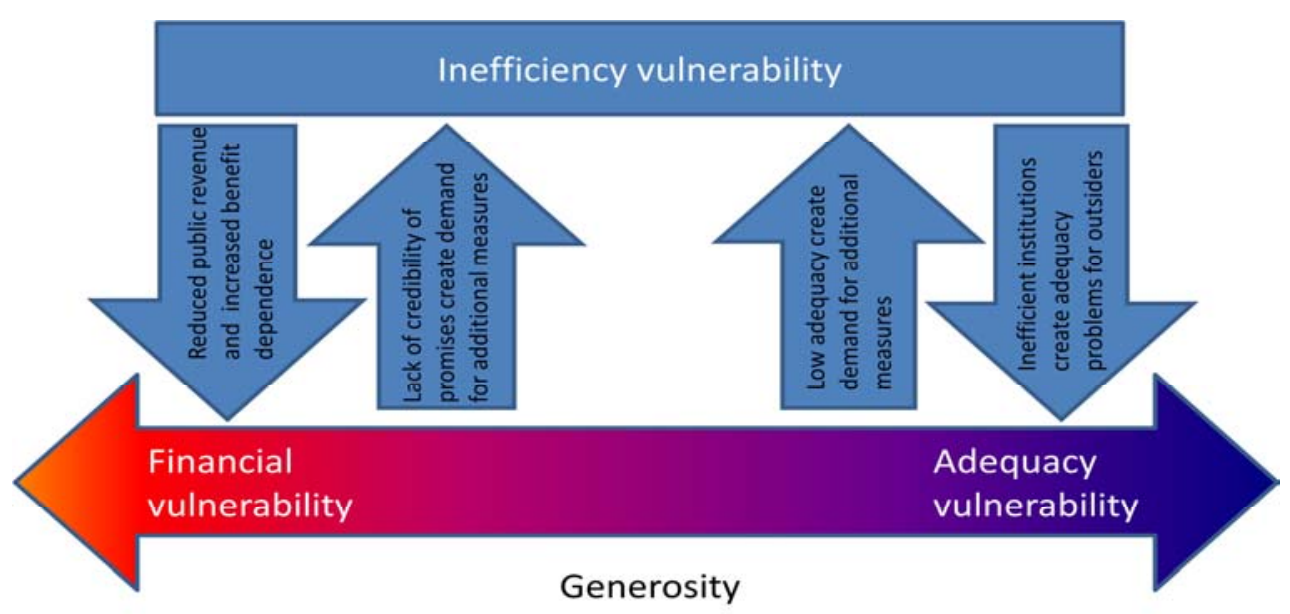

6. A third type of vulnerability can arise from the institutional set-up. Poor design of the scheme and its flanking policies can make the difficult political trade-off between adequacy and sustainability more pronounced. The design of the scheme itself can create vulnerabilities, for example, by reducing employment and productivity, which can lead to increasingly burdensome taxation, lower perceived fairness and insider-outsider frictions. These mechanisms could in turn reduce social cohesion and increase financial vulnerabilities in the long term. One example of such "inefficiency vulnerability" is when workers on permanent contracts are adequately covered by social insurance, while workers on temporary contracts or individuals who are discouraged from entering the labour force may experience a far lower degree of social protection. This situation creates insider-outsider issues and increases inequality.

7. Both too low risk sharing and too high generosity can and will lead to welfare losses (Andersen, 2013). Too low risk sharing is an issue in the BRIICS and in some OECD countries, as is explored in more detail below. The generosity and degree of redistribution provided by unemployment insurance schemes reflect to a certain extent different national preferences. While, for example, the English-speaking countries tend to show a higher acceptance of income inequalities and lower acceptance for large social transfers, the Nordic and Continental European countries tend to have stronger preferences for income equality and higher acceptance of large social transfers. In the absence of a widely-accepted social welfare function, a universally "correct" trade-off between financial stability and the adequacy of the safety cannot be established. If, however, the system is too generous to be sustainable, or the generosity is too low compared with national preferences, this could lead to populist pressures to introduce "quick fixes". A failure to reach a reasonable balance according to national preferences could therefore lead to the wrong kind of measures being implemented, like for example the protection of industries instead of increasing the safety net for the unemployed.

\section{The resilience of unemployment insurance schemes}

8. The main purposes of unemployment insurance schemes are risk-sharing and redistribution across individuals. ${ }^{2}$ In addition unemployment insurance has a counter-cyclical effect, thus enhancing macroeconomic stability (Andersen, 2013, Immervoll, 2012). An unemployment insurance scheme can be said to be resilient even during deep recessions if the system:

2. Any policy which is risk-sharing ex ante will always be redistributive ex post (Andersen, 2013). 
- does not run out of funds and does thus not require emergency transfers from the sovereign or resort to emergency rule changes to meet its financial obligations (financial soundness),

- ensures adequate income support to the unemployed according to social preferences (adequacy), and

- $\quad$ supports, or does not unduly hamper return to work, labour market flexibility and productivity growth (efficiency).

9. Each of these elements is affected both by the settings of an unemployment insurance scheme itself and by the wider labour market institutions of a country. As will be further discussed in Section 5, vulnerabilities are often created by complex interactions between unemployment insurance and other labour market institutions, rather than the set-up of the unemployment insurance scheme per se.

\section{Shocks and trends}

10. As a prominent automatic stabiliser and risk-sharing tool, unemployment insurance is intended to be a counter-cyclical and volatile spending item. The size of shocks that can hit unemployment insurance systems is well illustrated by the recent recession. Almost all OECD countries were hit, and GDP dropped by more than $5 \%$ in some countries. The cumulative GDP loss relative to potential amounts to more than $25 \%$ of 2012 GDP for Ireland while most Eastern European countries and BRIICs were little affected by the crisis. Labour market outcomes have diverged. Unemployment increased sharply with peaks in Greece and Spain, where 20 percentage points and almost 15 percentage points were added to the respective precrisis unemployment rates. In Germany, the United Kingdom and Japan employment growth was positive and unemployment has been lower than what could be expected given past relationships with output growth (OECD, 2013a). For the euro area as a whole, and for many euro area countries such as France, Italy and Spain the opposite has been the case, with higher job losses than what could be expected based on past relationships with economic growth. The uneven labour market impact of the recent crisis illustrates how aggregate shocks are quite heterogeneous across OECD countries and across time.

11. As a prominent automatic stabiliser and risk-sharing tool, unemployment insurance is a countercyclical and volatile spending item by design. During the recent crisis unemployment insurance and active labour market policy expenditure increased in most OECD countries (Figure 3). In 10 countries, spending more than doubled from 2007 to 2009-10. In some countries spending rose considerably more than the number of unemployed, reflecting both composition effects with a large inflow of new unemployed who are more likely to qualify for benefits, an extension of duration, less stringent eligibility criteria, more generous benefits and increased ALMP spending, while in others the increase was considerably smaller, mainly because of reduced coverage, pointing to possible adequacy problems. 
Figure 3. Unemployment and ALMP spending before and during the initial phase of the crisis

Average annual per cent changes, per capita spending in 2000 prices

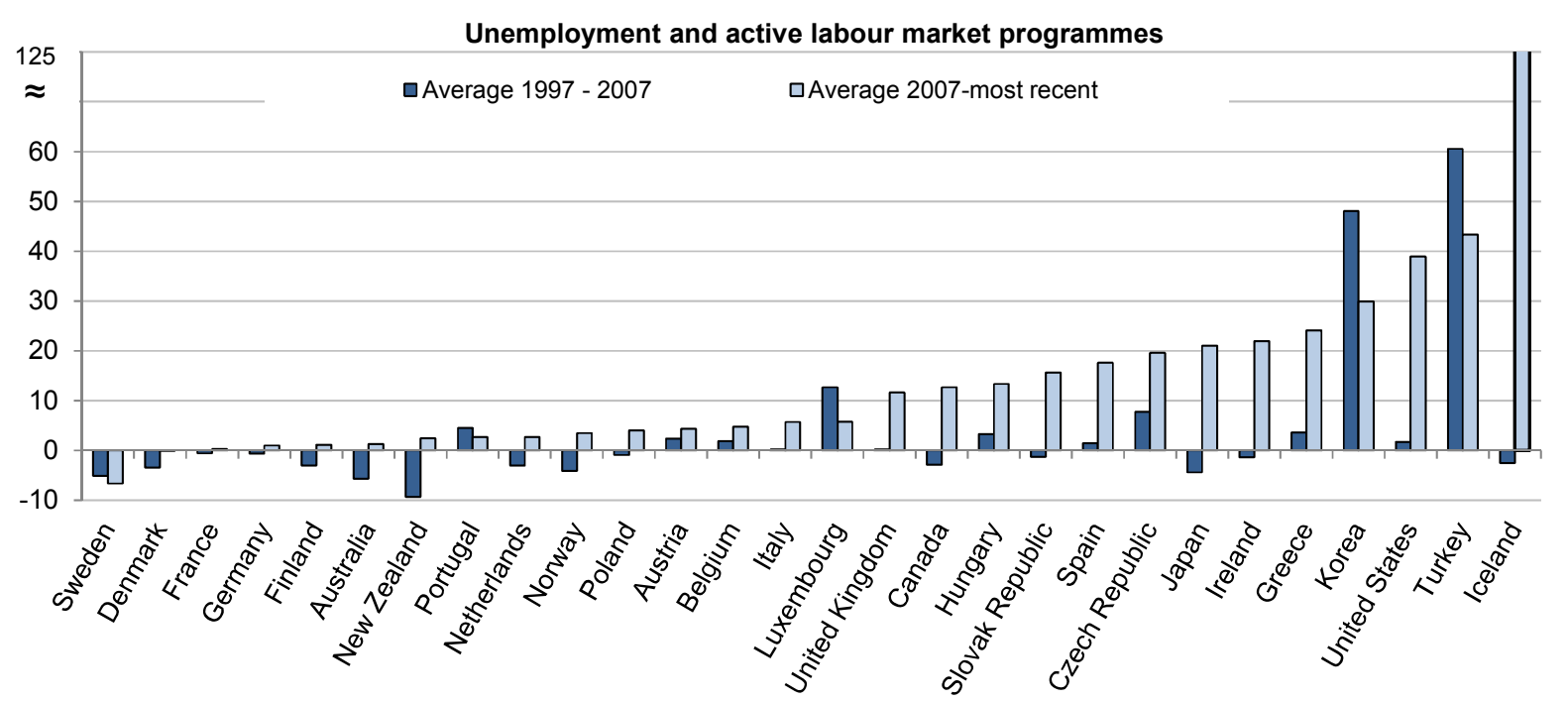

Note: Most recent data refer to 2010 for Australia, Germany, Ireland, Korea, Mexico, New Zealand and the United States. For all other countries shown, most recent data refer to 2009. Data are not available for Chile, Estonia, Israel, Slovenia and Turkey. Data are not shown for Switzerland, where the most recent data available refer to 2008.

Source: OECD Social Expenditure Database, September 2013.

12. The vulnerability of unemployment insurance schemes to adverse macroeconomic shocks depends on how shocks translate into unemployment fluctuations and whether they affect structural unemployment via hysteresis effects. The structural unemployment rate has drifted up between the 1960s and 1990s in the OECD on average. It was then stable during the 2000s, but has drifted up again during the recent crisis (Figure 4, Panel A). A rise in structural unemployment puts upward pressure on unemployment insurance spending.

13. Unemployment volatility is an important aspect of the vulnerability of unemployment insurance schemes to macroeconomic shocks. Estonia, Ireland and Spain are the countries with the highest volatility of the unemployment rate around the mean (Figure 4, Panel B). The variability of expenditure, however, depends not only on unemployment fluctuations, but also how they translate into higher expenditure, which can be captured by the elasticity of unemployment spending with respect to the number of unemployed (Figure 4, Panel C). 
Figure 4. Unemployment, volatility and expenditure response

Panel A. The NAIRU has increased during the crisis

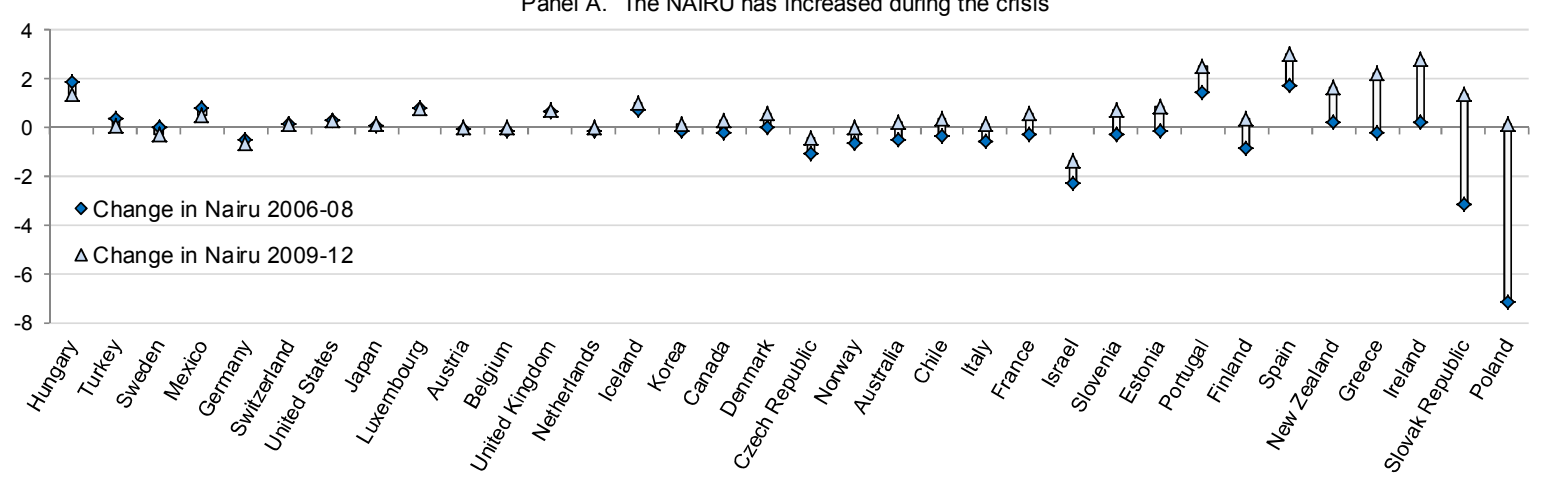

Panel B. Unemployment rate and volatility

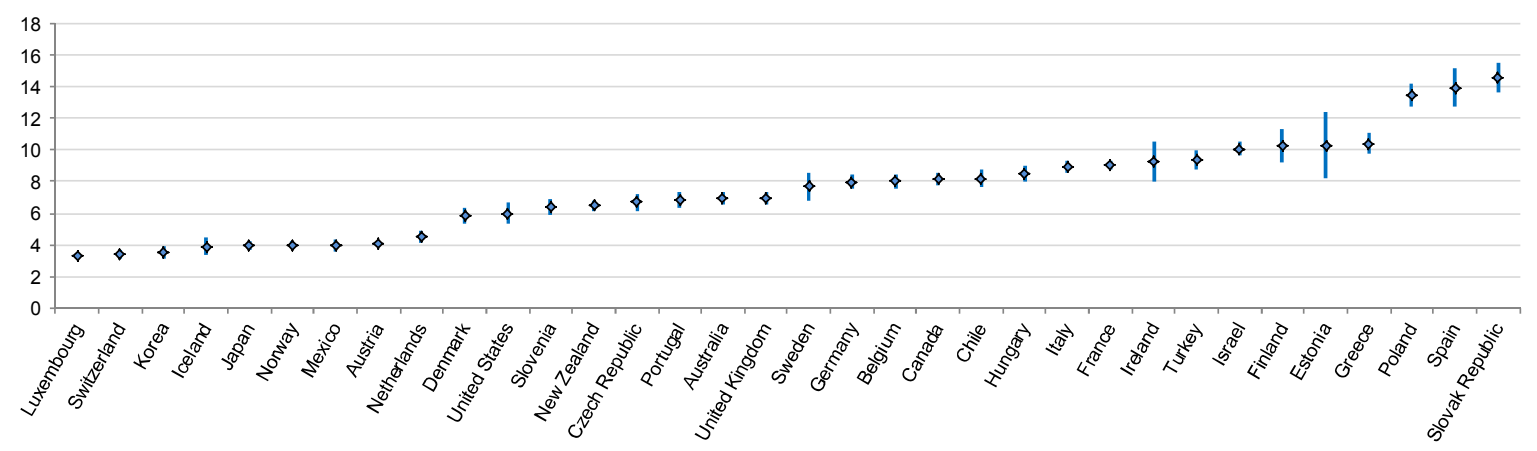

Panel C. Unemployment insurance expenditure elasticity to unemployment

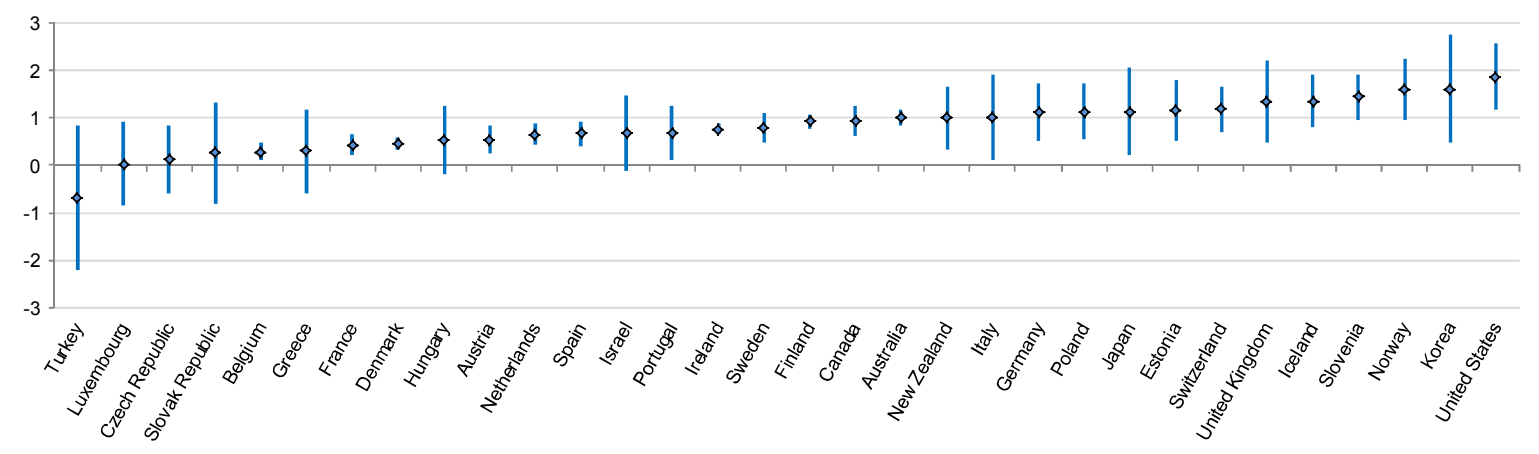

Panel D. Spending assymetries over the cycle exist in some countries

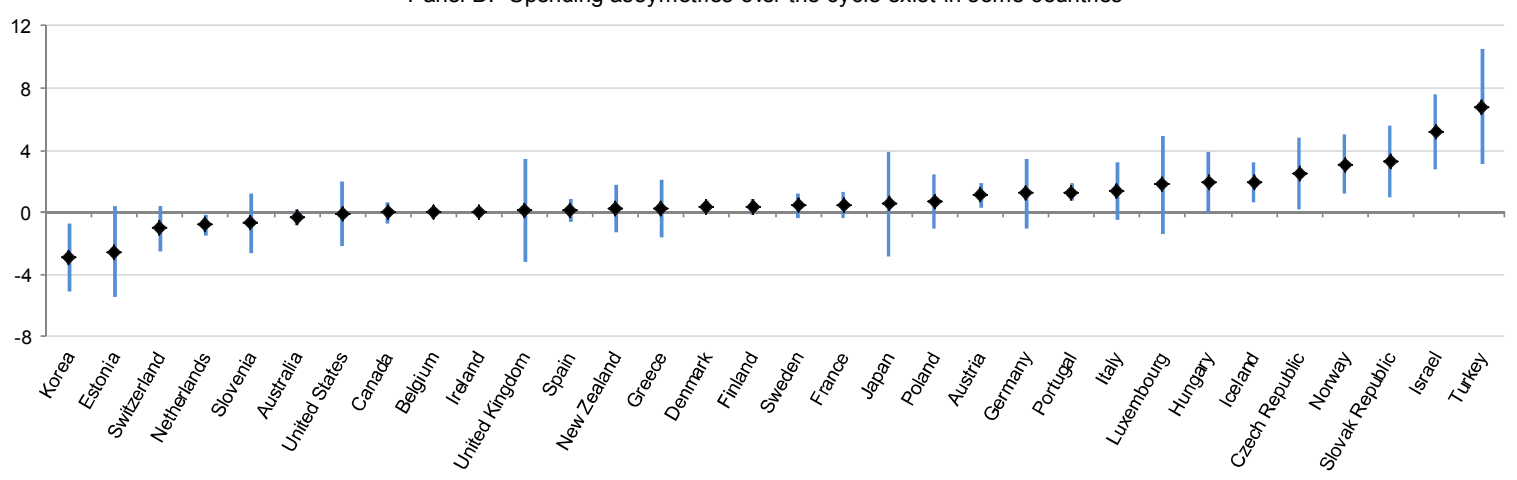

Note: Panel B shows the average unemployment rate from 1990-12 and 95\% confidence intervals around the averages. Panel C shows the expenditure elasticity of unemployment insurance with respect to unemployment, calculated with a simple bivariate OLS regression along with a $90 \%$ confidence interval of the regression coefficient. Panel D shows the difference of the elasticity of unemployment insurance expenditure to rising unemployment and declining unemployment with a $90 \%$ confidence interval. The sample period is 1990 to 2012 in panel B, C and D. The elasticities are based on historical data and are not necessarily relevant to current policy challenges for all countries.

Source: EO93 database; OECD Social Expenditure database; OECD calculations. 
14. The very existence of volatility can contribute to undermine the sustainability of the scheme, if spending increases more in bad times than it is reduced in good times, as it does in some countries (Figure 4, Panel D). On average in the OECD, a 1\% increase in the unemployment rate since 1990 has led to a $1 \%$ increase in unemployment insurance expenditure, while a $1 \%$ drop in unemployment has only led to a $0.5 \%$ reduction in expenditure. Cross-country differences are large, with some countries (Turkey, Israel, the Slovak Republic, Norway, the Czech Republic, Iceland, Portugal and Austria) showing large and statistically significant asymmetries.

15. Such "stickiness" of expenditure leads to unemployment insurance increasing more than the wage base, which is unsustainable in the long run (Box 1). Increasing benefits during a crisis and then maintaining a higher level can make good sense if benefit generosity or coverage are too low. On the other hand, increasing benefits might reduce work incentives and turn the cyclical increase in unemployment into a structural increase (hysteresis). This can deepen and prolong a downturn and lead to structural weaknesses if comparable measures to improve incentives and public finances in good times are held back due to institutional and political factors.

\section{Box 1. GDP shocks can lead to an upward creep in unemployment insurance spending}

A way of looking at the long-term financial soundness of unemployment insurance schemes is whether financing can be expected to keep pace with spending during shocks. In most countries the financing of unemployment insurance schemes is based on social security contributions levied on wages. For a given contribution rate, the vulnerability of a scheme increases when unemployment insurance spending shows a tendency to increase as a share of the total wage bill.

This type of vulnerability can be captured by stochastic simulations of the ratio of unemployment insurance spending to the total payroll. The unemployment insurance spending to the wage bill ratio can be projected to 2050 using stochastic simulations (Appendix A1). These past shocks are used in country-specific equations simulating the impact of such shocks on the ratio of unemployment insurance expenditure to the total wage bill. It is expected that the greater GDP volatility is, the larger will be the dispersion of the unemployment benefit-to-payroll ratio simulations. In addition, the skewness of the distribution of the unemployment spending-to-wage bill ratio is increasing with the degree of asymmetry of the GDP shock distribution and the difference in the response of the unemployment spending-to-wage bill ratio to positive and negative GDP shocks.

Some countries were more exposed to GDP shocks as illustrated by the differences in the sensitivity of unemployment spending and revenues to GDP shocks. However, whether future shocks will follow the patterns of the past is an open question and expenditure responses to shocks may change as fundamentals and institutions change. Figure 16 shows the average unemployment benefit-to-payroll ratio in 2007-10, the projected values in 2050 and the $90 \%$ confidence interval under the assumption that GDP shocks are the same as in the past. Countries such as Ireland, Denmark and Portugal face a central estimate much above today's level, whereas others (Finland, Spain and Italy) display high risks as their spending ratio distribution is heavily skewed towards the right. Some countries display a combination of several unfortunate trends, as is the case for Finland and Hungary, with high current spending, a substantial tendency to drift upwards as revealed by past stickiness, and high upside risks to spending. 
Box 1. GDP shocks can lead to an upward creep in unemployment insurance spending (cont.)

Figure 5. Vulnerability of unemployment insurance schemes to GDP shocks

Projected unemployment insurance expenditure as a ratio of the wage bill (2050)

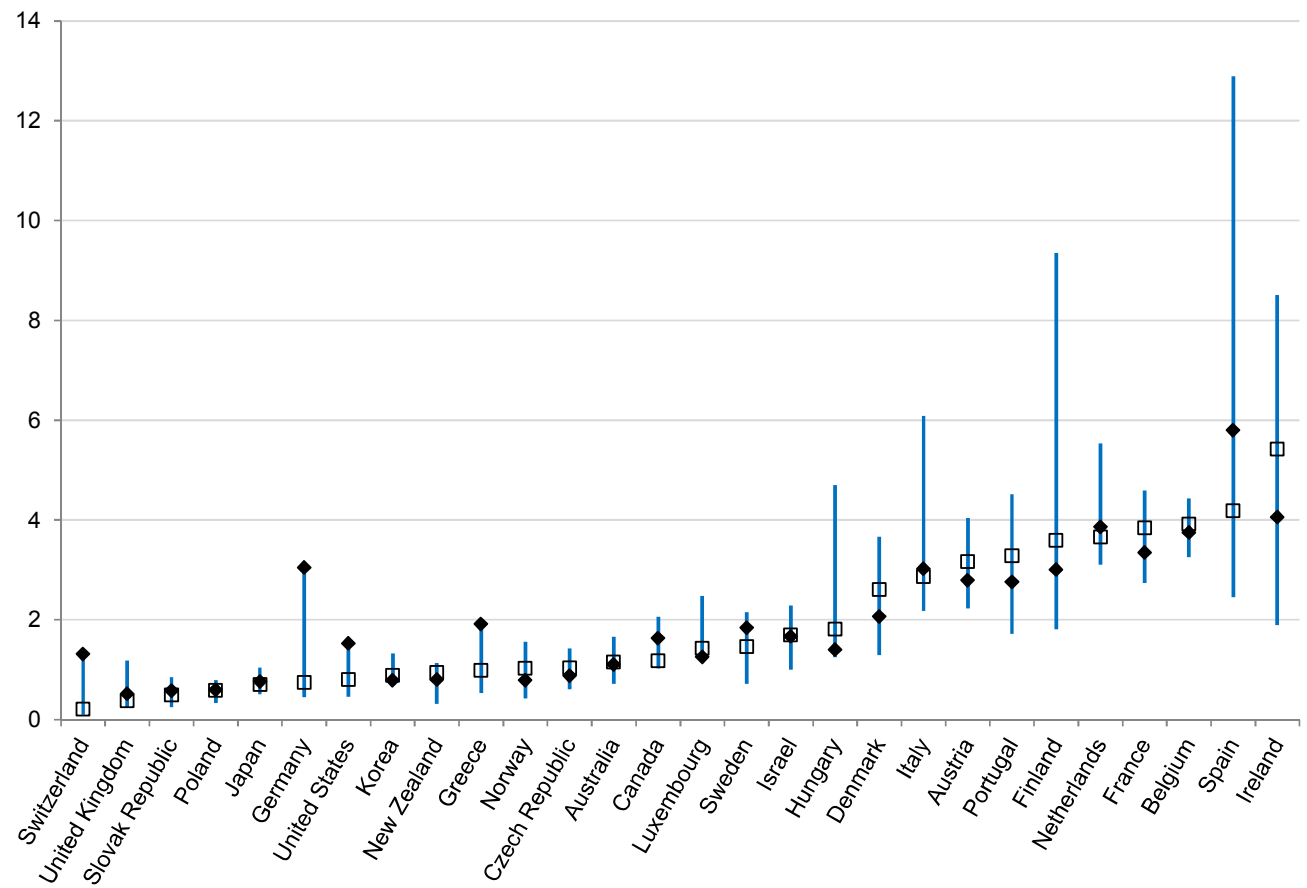

Note: The solid diamonds represent the 2007-10 average of the ratio of unemployment insurance spending to the wage bill; the squares represent the 2050 central projection (median); the lines represent the $90 \%$ confidence interval. The 2050 estimates and confidence intervals are based on country-specific equations of the ratio of unemployment insurance expenditure to the total wage bill on its lagged value and positive and negative output shocks. This model captures the asymmetric responses to positive and negative shocks. The methodology for extracting output shocks is described in Appendix A1.

Sources: OECD calculations; OECD Social Expenditure database, OECD Long-term Database Economic Outlook 93.

\section{Ageing and unemployment insurance schemes}

16. The recent labour market performance of older individuals has been good. The employment rate of older individuals increased, continuing a trend apparent before the crisis (OECD, 2013b). Earlier, older workers tended to withdraw from the labour market during downturns. Pension reforms, the phasing out of early retirement schemes and the tightening of eligibility criteria for other social transfer programmes that operated as de facto early retirement schemes have contributed to this improvement.

17. Unemployment rates among older workers are low relative to the average in almost all OECD countries. On the other hand, employment rates of older workers are still low in many countries, reflecting the tendency of older workers to leave the workforce rather than becoming unemployed. Reforms to increase employment among older workers and raising the retirement age may have the negative sideeffect of increasing unemployment, since closing the remaining routes to early retirement and a better screening in disability schemes would increase participation rates of older workers, of which some will have difficulties finding a job. 


\section{Migration, employment and unemployment insurance}

18. In 2012, the unemployment rate of immigrants in OECD countries was on average considerably above that of natives (Figure 6). Immigrants also tend to be more vulnerable to shocks, with a stronger increase in unemployment during the recent crisis than among natives. The immigrant unemployment rate is highest in those countries which were the hardest hit by the crisis. These countries have also cut back on public funds devoted to integration policies. Measures to integrate immigrants into labour markets in the destination country, as well as language, culture and skills play a role in shaping the labour market performance of immigrants. The propensity to be unemployed varies considerably across different immigrant groups. Mexicans in the United States have today the lowest employment rates among the foreign-born, partly as a result of their strong presence in construction and manufacturing sectors and their over-representation among the low-skilled. Also migrants from North Africa in Europe have experienced sharp employment losses. At 26.6\%, their unemployment rate reached a record high in 2012.

Figure 6. Unemployment rates are often higher among immigrants than natives

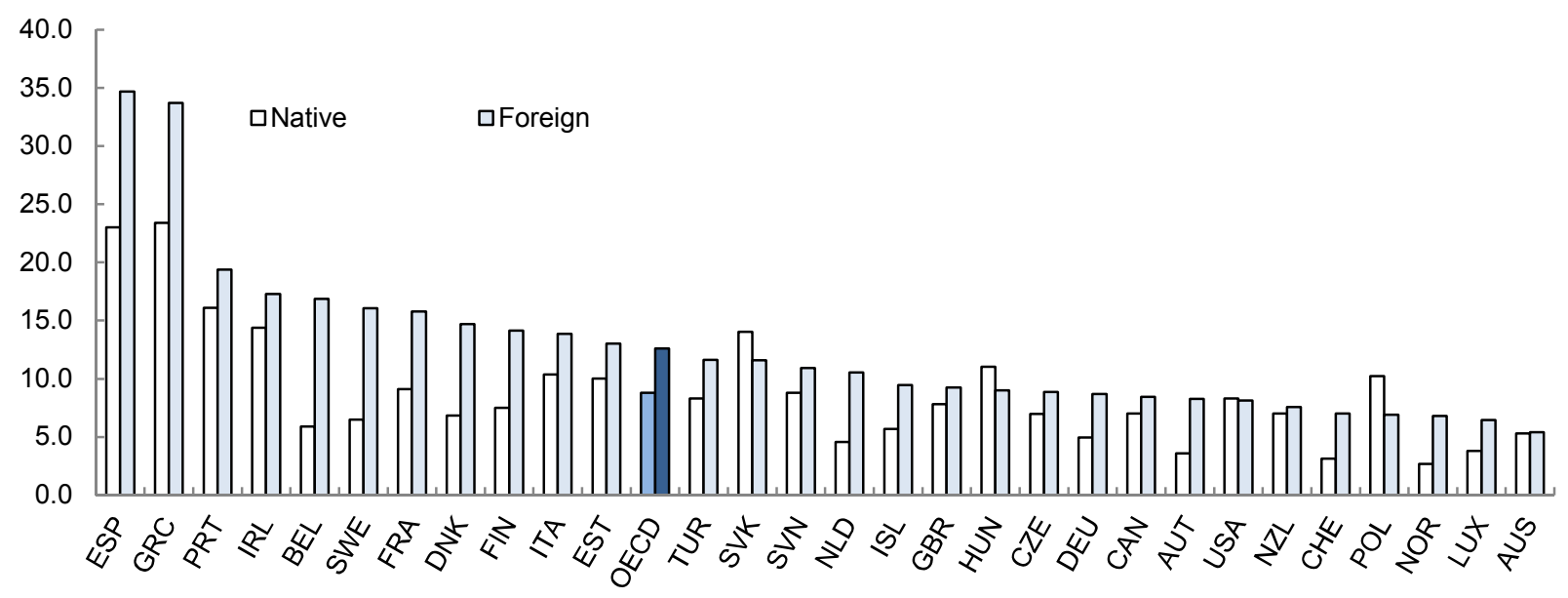

Note: Data refer to the working-age population (15-64).

Source: OECD (2013), Migration Outlook 2013.

19. The population projections by the UN and Eurostat assume that past migration patterns will largely persist and strong flows of South-to-North migration are expected to continue. For the countries, which have difficulties with integrating immigrants into the labour market, this does not bode well for future unemployment developments. On the other hand, migration projections based on a gravity model indicate that the expected rapid income convergence between OECD and emerging countries will lower the economic incentives for migration, and that the OECD may experience net emigration of economic migrants between 2010 and 2060 (Braconier and Westmore, 2014). While the United States could experience a net inflow of migrants, net emigration would be especially marked for the euro area, which would experience a substantial decline of the inflow of low-skilled immigrants that have traditionally moved to the euro area, owing to relatively strong projected wage growth in their countries of origin. This would reduce unemployment in the countries that have difficulties in integrating immigrants. 


\section{Policies to build resilient unemployment insurance schemes}

20. To reduce the financial vulnerability of unemployment insurance schemes to crises, policies that lower unemployment and reduce economic and unemployment volatility should be considered. Such policies include both the settings of the unemployment insurance scheme itself and flanking policies. Some of these policies entail trade-offs between the cost and efficiency and the adequacy of the unemployment insurance scheme, while others are generally good on all counts, by e.g. both reducing the individual cost of unemployment while at the same time reducing average unemployment over the cycle and thus reducing the cost of the unemployment insurance scheme. The effects of all individual policies depend on the configuration of flanking policies.

\section{Trade-offs between financial sustainability, adequacy and efficiency}

21. Unemployment insurance is highly counter-cyclical and contributes to dampen negative GDP shocks. By reducing benefits and coverage and by increasing contributions in times of crisis the financial risks of the unemployment insurance scheme can in principle be shifted from the public sector to individuals. However, if too much risk is off-loaded on individuals, unemployment insurance will partly lose its purpose as a risk-sharing and redistributive tool and as an automatic stabiliser. There is also a case for the countries with the least generous unemployment insurance systems to do the opposite, to temporarily increase duration and replacement rates during recessions.

\section{Eligibility criteria}

22. If eligibility criteria are too strict, unemployment insurance will not perform its core function as a risk sharing tool in the face of an unemployment shock. Also the automatic stabilisers will be less powerful. In countries with very strict eligibility criteria, such as Italy and Slovakia, ${ }^{3}$ a very low percentage of the unemployed is covered by unemployment insurance. A well-designed social safety net incentivises labour market entry by rewarding attachment to the labour market. This is an argument for applying eligibility criteria, especially in the case of generous unemployment benefits. The average eligibility threshold in the OECD is 11 months of work or unemployment insurance membership ${ }^{4}$ or equivalent earnings ${ }^{5}$. When eligibility criteria are very stringent, as e.g. in Italy and Slovakia, a very low percentage of the unemployed will be covered by unemployment insurance. In such cases, unemployment insurance will not perform its core functions as a risk sharing, redistribution tool and as an automatic stabiliser. Strict eligibility criteria together with labour market duality can further accentuate inequalities between workers on fixed term and open-ended contracts, if temporary work prevents workers on fixed-term contracts from benefiting fully from unemployment insurance.

23. Youth and medium-skilled workers were the most hit by the surge in unemployment since 2009, but the social impact was hardest for the young, who have faced soaring poverty. Countries hard hit by the

3. In Slovakia unemployment insurance eligibility requires 36 months of working (the highest in the OECD) and in Italy 24. Unemployment insurance duration (total benefits the first 5 years of unemployment divided by initial monthly benefits) is 2.3 months in Italy and 4.8 months in Slovakia. This is low compared with the OECD average and contributes strongly to low coverage.

4. In some countries the threshold is defined as a minimum period of membership in the unemployment insurance scheme. This membership is tied to work status, but does not necessarily mean that the individual has been continuously in work for the full period.

5. In some countries the thereshold is defined as a minimum level of labour income during the period before unemployment. "Equivalent earnings" is calculated as this threshold divided by the average wage in the country in question. 
crisis (such as Estonia, Greece, Spain, Portugal and Italy), have been the least able to shield their youth from rising poverty (Figure 7). The large numbers of youth who are unemployed and not eligible for unemployment insurance are not covered by conditionality. This can pose a long-term problem as they can become disconnected from the labour market. The most important policy to counter this is labour market reform, especially by reducing labour market duality, and other targeted policies such as education and training, a lower minimum wage for the young and perhaps youth guarantees, ${ }^{6}$ a policy pursued by some OECD countries (OECD, 2013b). Loosening eligibility requirements may also be an option in this regard, especially in times of severe crisis, as discussed below.

Figure 7. Youth poverty has soared during the crisis, while older people were better protected

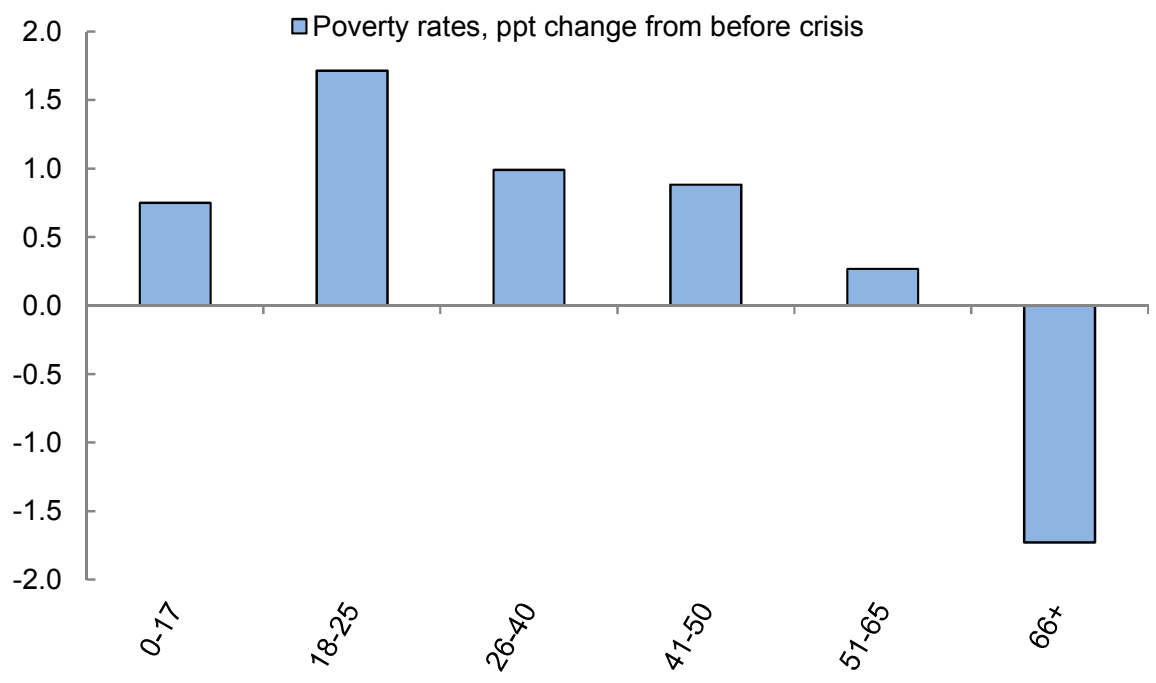

Note: The figure shows the average of 32 OECD countries The poverty rates refer to $50 \%$ of the median income after taxes and transfers, percentage point change from 2007 (2006 for Chile and Japan, 2005 for Switzerland, France, Israel and the United States and 2004 for Australia, Germany, Finland, Mexico, Norway and Sweden) to 2010 (2009 for Switzerland, Chile, Hungary, Ireland, Japan and Turkey).

Source: OECD Income Distribution database, September 2013.

24. As shown in Figure 8, the duration of unemployment insurance, which is discussed in the next section, is the feature that seem most closely related to the coverage of unemployment insurance, while the strictness of eligibility and labour market duality seem to limit coverage in some of the countries that display the lowest coverage, such as Korea, Italy, Poland, Turkey and the Slovak Republic.

6. Guaranteeing that all young people under 25 get a good-quality, concrete offer for a job, apprenticeship, traineeship, or continued education adapted to each individual need and situation within four months of them leaving formal education or becoming unemployed (European Council, 2013). 
Figure 8. Unemployed covered by unemployment insurance

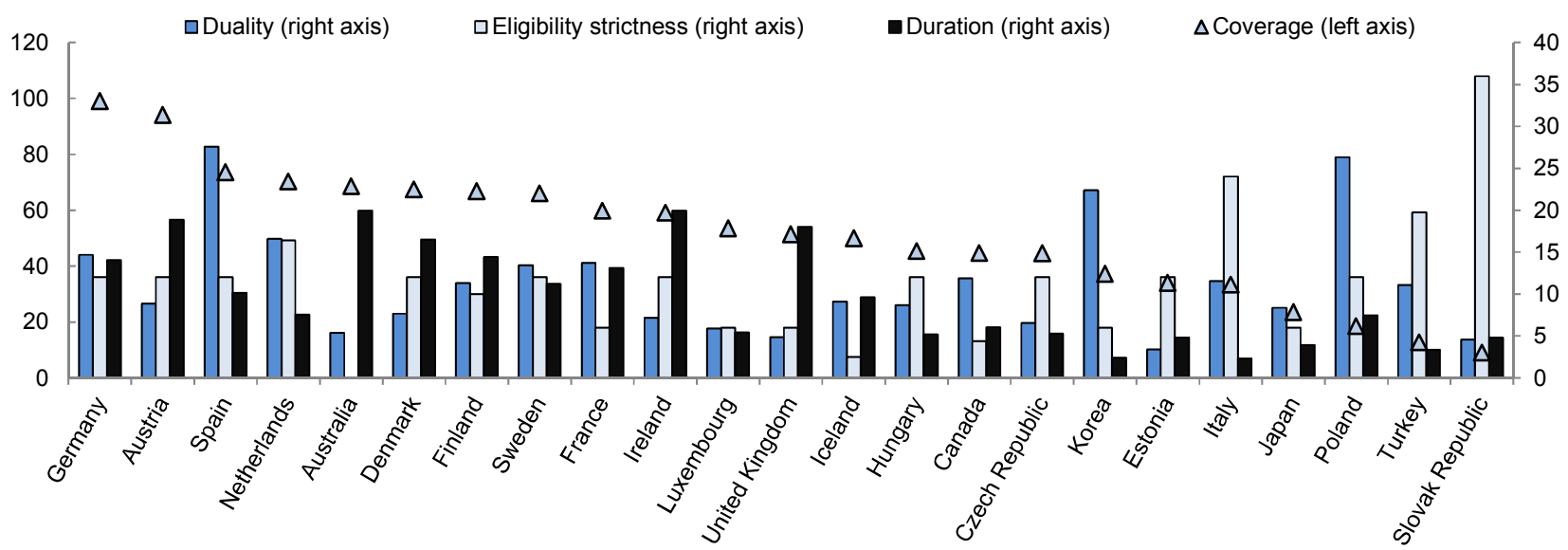

Note: Coverage refers to persons receiving unemployment insurance benefits as a per cent of the unemployed (Survey based, 2007-08). Duality (2008) is measured by the percentage of males on temporary contracts. Eligibility (2007) is measured as the number of quarters of work, UI membership or equivalent earnings before becoming eligible. Duration (2008) is measured in months. The duration indicator is a synthetic measure of how quickly replacement rates are tapered. It is calculated as the cumulative fiveyear replacement rate divided by the initial replacement rate. For the United Kingdom and Australia: Includes Jobseeker's allowance (social insurance and social assistance).

Source: OECD calculations based on the OECD Tax Benefit model; OECD (2010), "Labour Market Statistics: Full-time part-time employment - common definition: incidence", OECD Employment and Labour Market Statistics (database). doi: 10.1787/data-00299en (Accessed on 02 April 2014); Venn, D. (2012), "Eligibility Criteria for Unemployment Benefits: Quantitative Indicators for OECD and EU Countries"; OECD Social, Employment and Migration Working Papers, No. 131; Benefits and wages policy overview tables (www.oecd.org/els/benefitsandwagespolicies.htm); OECD Employment Outlook 2011.

\section{Duration and replacement rates}

25. When an unemployment shock hits, generous unemployment insurance benefits can shield people from being pushed into poverty and also allow for better job matching. Replacement rates in a number of OECD countries are, however, too low to keep individuals out of relative poverty. While unemployment benefits in the United Kingdom and Australia are means-tested and generally combined with top-ups to cover living expenses, replacement rates in a number of other OECD countries are too low to keep individuals out of relative poverty. A single person with in-work earnings of $67 \%$ of the national average wage will for example end up living in poverty ( $50 \%$ of median wage) in one out of two OECD countries (Figure 9, Panel A). A lone parent with the same in-work earnings would receive additional benefits to cover living costs of dependent children in most countries, and would end up below the $50 \%$ poverty line in on out of four countries. Workless households are on average more than seven times as exposed to poverty as households in which at least one of the household members are in work (Figure 9, Panel B). 
Figure 9. Worklessness and poverty

Panel A. Unemployment and other benefits are often not generous enough to avoid poverty

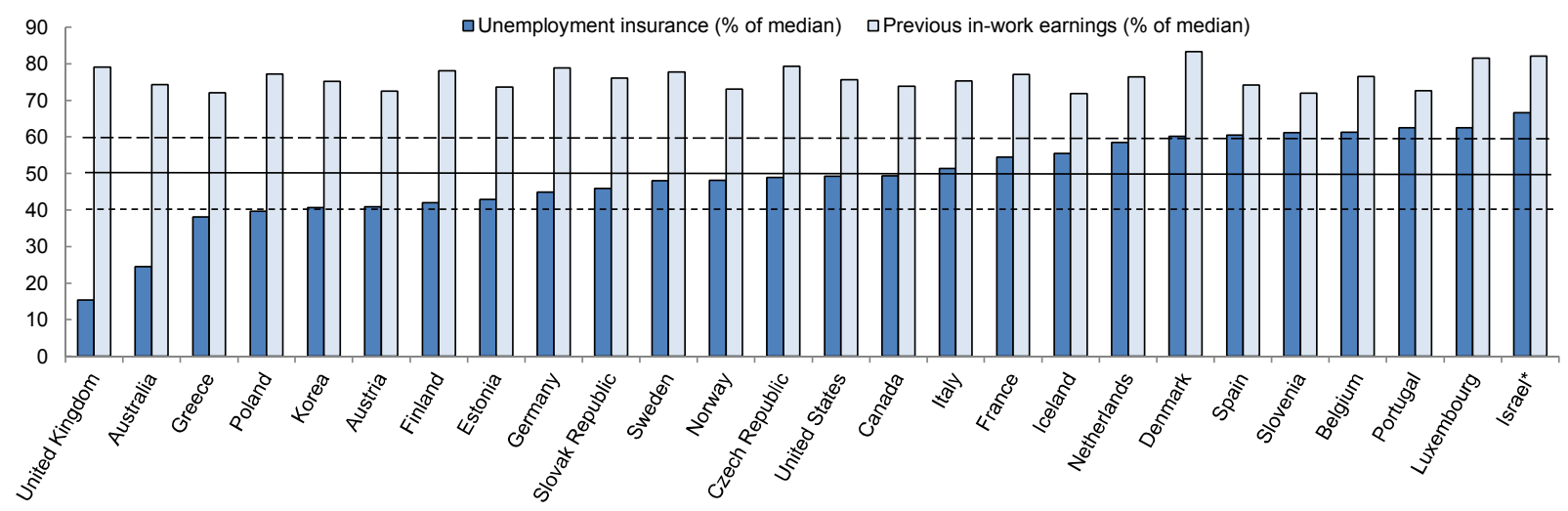

Panel B. Workless households are on average seven times more prone to be poor than working households

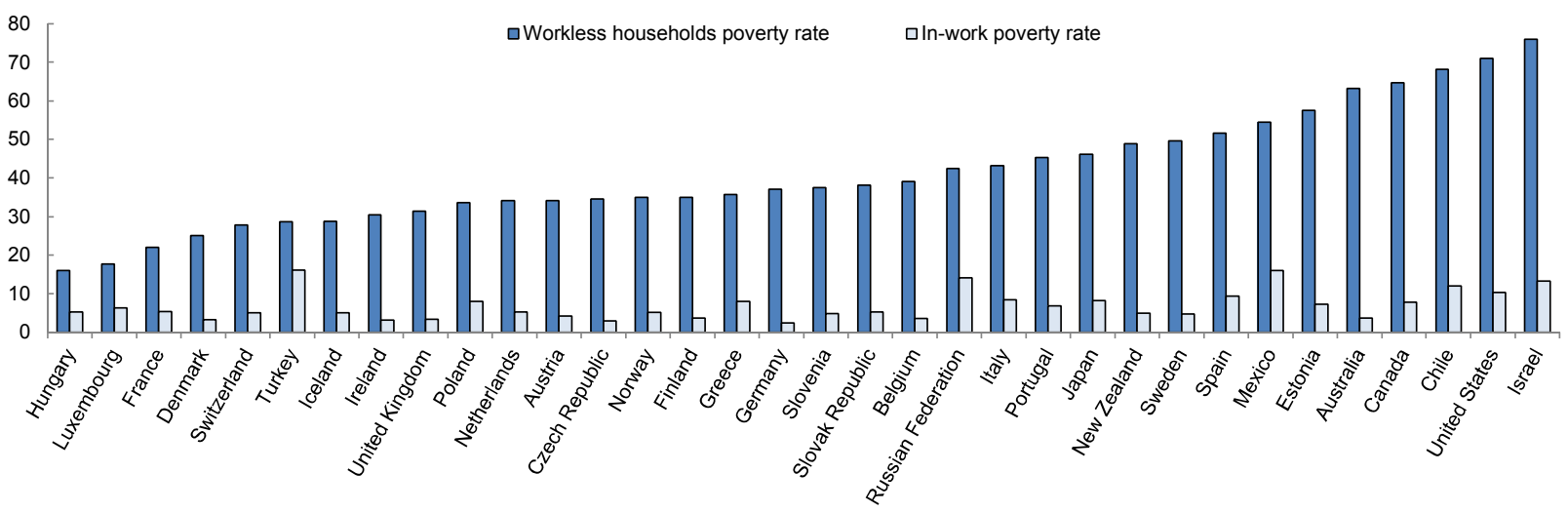

Note: All data refer to net income after taxes and benefits. Panel A is based on a single person household, with the following assumptions: pre-unemployment earnings are assumed to be $67 \%$ of average wage; initial phase of unemployment, but following any waiting period; any income taxes payable on unemployment benefits are determined in relation to annualised benefit values (i.e. monthly values multiplied by 12) even if the maximum benefit duration is shorter than 12 months. For the United Kingdom and Australia, unemployment insurance includes jobseeker's allowance (social insurance and social assistance). Social assistance topups to cover e.g. housing are not included.

Source: OECD Database on Income Distribution and Poverty (Panel A), calculations based on OECD Tax Benefit model (Panel B).

26. While generous unemployment insurance schemes provide a powerful shock absorption mechanism, they can also reduce job search incentives when they are combined with long unemployment insurance duration. This is especially true for low income earners and for those unemployed who are likely to earn a lower wage when re-entering the labour market. Countries who offer high initial replacement rates should therefore provide generous benefits only for a short duration to ensure that incentives for job search are not undermined. Countries with the highest generosity in the OECD in 2011 exhibit very high initial replacement rates that are also reduced very little for the first five years of unemployment (Table 1). In some unemployment insurance schemes, where replacement rates are clearly too high to give good job search incentives, replacement rates should be tapered. 
Table 1. Net replacement rates and duration

2011

\begin{tabular}{|c|c|c|c|}
\hline & $\begin{array}{c}\text { Net replacement rate } \\
5 \text { year average }\end{array}$ & $\begin{array}{c}\text { Net replacement rate } \\
\text { initial }\end{array}$ & $\begin{array}{c}\text { Net replacement rate } \\
\text { duration (in years) }\end{array}$ \\
\hline Belgium $^{1}$ & 64 & 70 & 4.6 \\
\hline Ireland & 62 & 62 & 5.0 \\
\hline Austria & 59 & 63 & 4.7 \\
\hline New Zealand & 49 & 49 & 5.0 \\
\hline Portugal & 47 & 76 & 3.1 \\
\hline Australia & 47 & 47 & 5.0 \\
\hline France & 44 & 67 & 3.3 \\
\hline Finland & 43 & 61 & 3.5 \\
\hline Germany & 41 & 65 & 3.1 \\
\hline Sweden & 40 & 59 & 3.4 \\
\hline Norway & 40 & 73 & 2.7 \\
\hline Iceland & 37 & 73 & 2.5 \\
\hline Spain & 36 & 71 & 2.5 \\
\hline Denmark & 35 & 74 & 2.4 \\
\hline United Kingdom & 31 & 34 & 4.6 \\
\hline Netherlands & 30 & 76 & 2.0 \\
\hline Canada & 26 & 72 & 1.8 \\
\hline Luxembourg & 25 & 87 & 1.4 \\
\hline Switzerland & 24 & 80 & 1.5 \\
\hline Slovenia & 21 & 82 & 1.3 \\
\hline United States & 19 & 51 & 1.9 \\
\hline Slovak Republic & 16 & 66 & 1.2 \\
\hline Poland & 16 & 53 & 1.5 \\
\hline Hungary & 16 & 64 & 1.2 \\
\hline Japan & 14 & 62 & 1.1 \\
\hline Greece & 14 & 48 & 1.4 \\
\hline Estonia & 14 & 58 & 1.2 \\
\hline Italy & 9 & 68 & 0.7 \\
\hline Turkey & 8 & 47 & 0.8 \\
\hline Czech Republic & 7 & 66 & 0.6 \\
\hline Korea & 6 & 50 & 0.6 \\
\hline OECD Median & 30 & 65 & 2.0 \\
\hline OECD Mean & 30 & 64 & 2.4 \\
\hline
\end{tabular}

Note: Initial replacement rate and five year average are calculated as unweighted averages for four different family types (single person households, lone parents, a one-earner married couple with no children, and a one-earner married couple with children) and on two different initial earnings full-time levels (of $67 \%$ and $100 \%$ of AW). Any income taxes payable on unemployment benefits are determined in relation to annualised benefit values (i.e. monthly values multiplied by 12) even if the maximum benefit duration is shorter than 12 months. For married couples the percentage of AW relates to the previous earnings of the "unemployed" spouse only; the second spouse is assumed to be "inactive" with no earnings and no recent employment history. Where receipt of social assistance or other minimum-income benefits is subject to activity tests (such as active job-search or being "available" for work), these requirements are assumed to be met. Children are aged four and six and neither childcare benefits nor childcare costs are considered. Calculations are after tax and including unemployment benefits and family benefits. No social assistance "top-ups" or cash housing benefits are assumed to be available in either the in-work or out-of-work situation. United Kingdom and Australia: Unemployment insurance includes Jobseeker's allowance (social insurance and social assistance). The duration indicator is a synthetic measure of how quickly replacement rates are tapered. It is calculated as the cumulative five-year replacement rate divided by the initial replacement rate.

1. The unemployment benefit system in Belgium was reformed in 2012, with higher initial replacement rates followed by a gradual reduction (16 to 48 months following unemployment depending on tenure) to a level just above social assistance (OECD, 2013c).

Source: The OECD Tax Benefit model. 


\section{Short-time working schemes can reduce unemployment peaks but come with a cost}

27. During the recent crisis, the sensitivity of unemployment to GDP has differed significantly from country to country. While some countries shed a lot of workers and productivity increased (Estonia, Iceland, Ireland and the United States amongst others), others experienced less severe losses of employment, compensated by a fall in hours worked and labour productivity (Figure 10). In Germany short-term working schemes are institutionalised, while in countries such as the United Kingdom the high degree of labour hoarding during the downturn remains largely unexplained. Clearly, in those countries that absorbed the slump mainly through lower productivity, the labour market consequences have been less severe. On the other hand, publically subsidised short-time working schemes also represent a cost for unemployment insurance schemes. It is not clear whether it is more expensive for a UI system, if employers achieve a reduction in hours worked via laying off workers, or if employers adjust by cutting average hours with the workers put on short-hours applying for partial unemployment benefits. Unemployment insurance and short-term working schemes also differ in how earnings losses are distributed in the population (Immervoll et al., 2010). Short-time working schemes can also lead to inefficiencies through loss of productivity gains as workers are not reallocated to more productive jobs. It can furthermore lead employers and employees to collude to extract state transfers even when such transfers are no longer needed. The design of short-time working schemes is crucial in dealing with these issues (Boeri and Bruecker, 2011). The extent to which GDP losses result in employment losses, as opposed to reduced productivity has varied across countries and time. Japanese employers for example relied much more heavily on hour's reductions following the recent crisis than they did following the Asian crisis in the late 1990s. This pattern suggests that all countries, also those with a muted employment response to the recent crisis, need to be prepared to deal with strong recessionary upsurges in unemployment in the future.

Figure 10. Decomposition of GDP losses during the initial phase of the recession

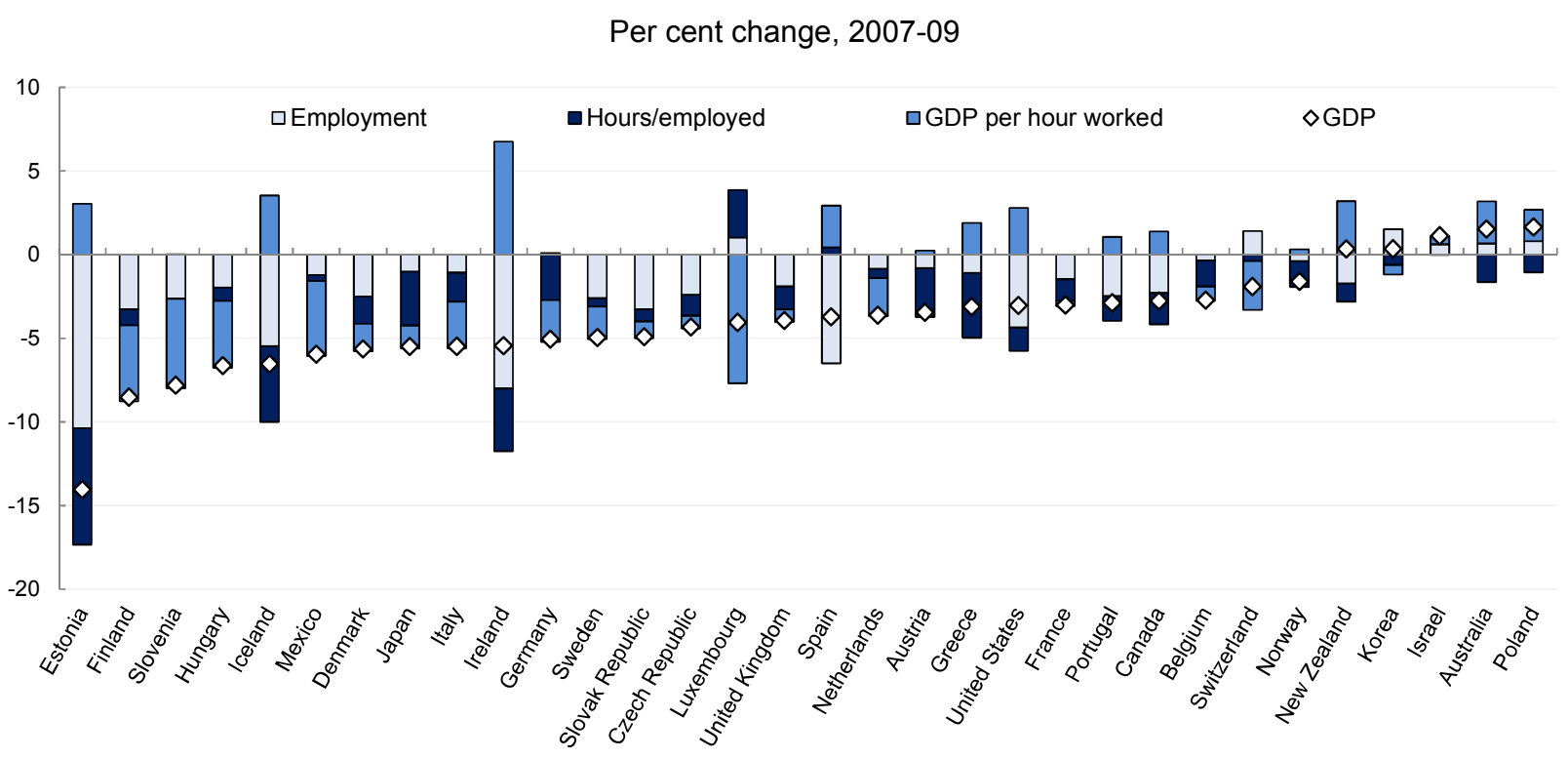

Note: GDP equals GDP per hour worked times hours per employed times employment. The employment contribution is calculated by keeping hours and GDP per hour constant at their 2007 level, changing employment to its 2009 level and calculating the resulting GDP growth rate. The same is done for the other variables.

Source: OECD Economic Outlook 93; OECD calculations. 


\section{Policies that enhance financial soundness, adequacy and efficiency}

\section{Effective activation policies - higher adequacy with lower welfare losses}

28. When a crisis hits, there is a tension between ensuring financial soundness on the one hand and adequate income support for the unemployed on the other. Even though they are costly in the short term, effective activation policies with job search conditionality as the core make it possible to improve financial soundness with a minimum sacrifice of adequacy. They lower the cost borne by individuals who lose their jobs by more efficient matching and shorter unemployment spells. The costs for society are reduced by both higher activity and lower unemployment insurance expenditure (Bassanini and Duval, 2006; Andersen and Svarer, 2007; Andersen, 2013). Different policies fit different groups of unemployed (Box 2).

29. Figure 11 shows that activation policies in some of the countries with the strongest rise in unemployment during the recent crisis have probably not been as responsive as required. Strong increases of unemployment combined with fiscal consolidation have left active labour market policies lagging in countries such as Ireland and Spain. These countries already boasted fairly high levels of spending on activation policies, but were not able to increase spending at the same pace as the rise in unemployment. In Mexico, the United States and New Zealand spending on activation policies was relatively low at the outset, and it has not kept pace with the surge in unemployment either. Other countries, such as Hungary, Portugal, Poland and Belgium, have scaled up active labour market policies more than the rise in unemployment. Korea, Slovenia, Estonia and Japan have scaled up activation policies significantly in percentage terms during the crisis, but from very low initial levels compared with the OECD average.

Figure 11. The responsiveness of active labour market policies to unemployment

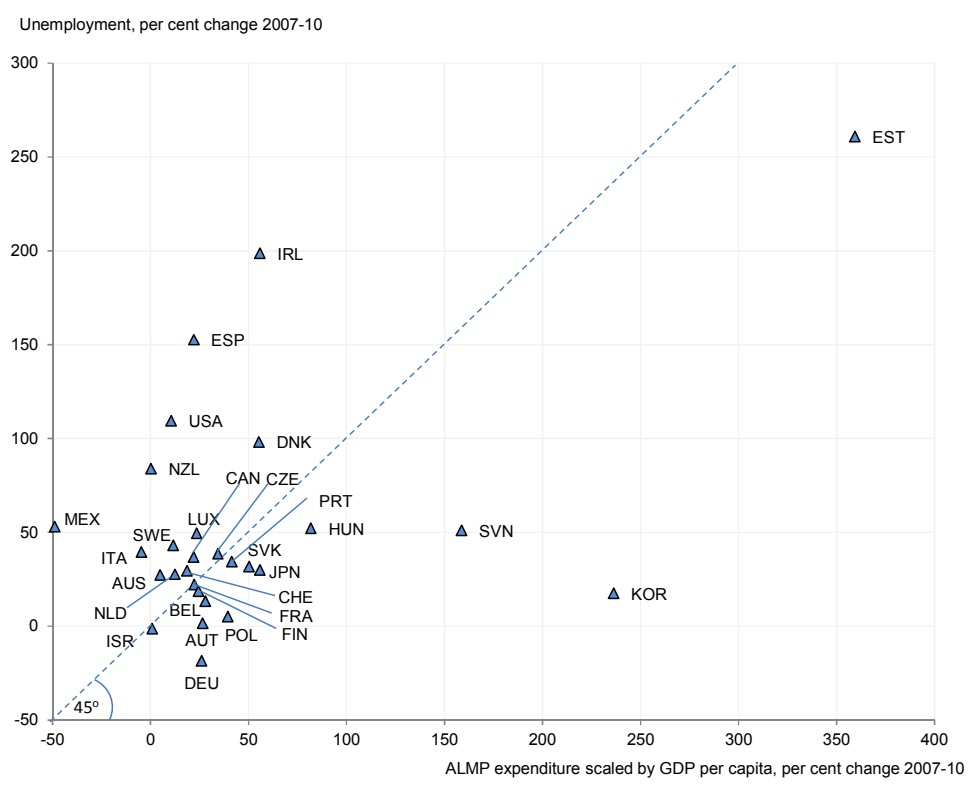

Note: ALMP expenditure is scaled by GDP per capita to ensure comparability across currencies.

Source: OECD Social Expenditure Database. 


\section{Box 2. OECD evaluations of activation policies}

Triggered by marked differences in how well countries with developed welfare states were dealing with youth and long-term unemployment associated with the economic shocks and policy mistakes of the 1970s and 1980s, comprehensive studies by the OECD were carried out (Martin, 2000; OECD 1994, 2007 and 2013b). Activation policies that look similar in function and in purpose may yield very different results in different national circumstances. This reflects to a large degree differences in organisation and implementation, but can also be coloured by other labour market institutions. Some principles to guide successful activation policies do however, emerge from these studies:

A strong, employment-focused activation system which assists with job search, matching and reducing barriers is the cornerstone of activation policies for countries with well-developed systems of income support. To be effective, the activation apparatus must have the necessary staff, systems and mandates to enforce job-search conditionality and mandatory referrals to available jobs and active labour market policies with benefit sanctions.

Widening the scope of job-search conditionality to new groups of claimants, such as lone parents and older workers, has contributed to increasing employment in several OECD countries. Such reforms should not come at the expense of the resources allocated to the activation of workers with full capacity to work. While reducing inactivity, including more disadvantaged groups such as lone parents and disability recipients in the conditionality regime will inevitably increase the recorded unemployment rate.

Compulsory participation in active labour market policies after a period of unsuccessful job search can help reduce the risk of long-term unemployment and labour market exit. Nonetheless, only four countries referred to in the OECD (OECD, 2007) study (Australia, Denmark, Sweden and the United Kingdom) were considered to have such mandatory programmes for all benefit recipients passing a specified spell of unemployment. It is furthermore advisable to leave participants in ALMPs some time for job search, which may facilitate finding work even before the end of the programme. For most programmes, e.g. job search training and work experience placements, the principle of continuing job-search verification with a requirement to take up any suitable job offer seems reasonable. Vocational training programmes which are expected to deliver a certificate upon completion should probably be an exception. However, over half of the countries examined in the OECD (OECD, 2007) study exempted programme participants from any job-search requirements.

High spending on active labour market policies is not a guarantee for successful outcomes. If such funds are used in an inefficient way, they may even increase unemployment and contribute to continuing benefit dependency. One example of this is Finland in the early 1990s. Following long-term unemployment, the unemployed and social assistance claimants were guaranteed placement in a subsidised public sector job. This placement led to requalification for unemployment benefits, and the system cemented high unemployment rates caused by rotation between jobs and unemployment. Also Ireland in the 2000s had high ALMP expenditure and a range of employment services were funded. Participation was, however, voluntary, benefits were high and conditionality and job-search criteria weak, partly due to low staffing. These weaknesses led to unemployment staying at relatively high levels even during a period of strong growth (OECD, 2013b). Direct job creation typically provides few long-run benefits for neither claimants nor society, but could be useful for the most disadvantaged job seekers (Martin, 2000).

\section{Closing routes to early retirement and disability schemes}

30. Early retirement and disability schemes can be a substitute for unemployment insurance. As such, they tend to improve the financial soundness of unemployment insurance schemes, when an unemployment shock hits. But they also undermine both labour supply and potential growth and the sustainability of the overall government finances, because they are not necessarily subject to activation measures and people tend to stay in these schemes until retirement. While curbing inflows into these other benefit schemes will increase unemployment insurance expenditure, it will also increase chances of reemployment, reduce benefit dependency, increase growth and generally also increase earnings prospects for the individuals concerned. The effect on the public finances from curbing inflows to early retirement and disability schemes is likely to be positive, but depends on the generosity of the different benefits and to which extent such curbs raise the employment of older workers, which is still low in many countries (Figure 12). 
Figure 12. Employment and unemployment of older workers

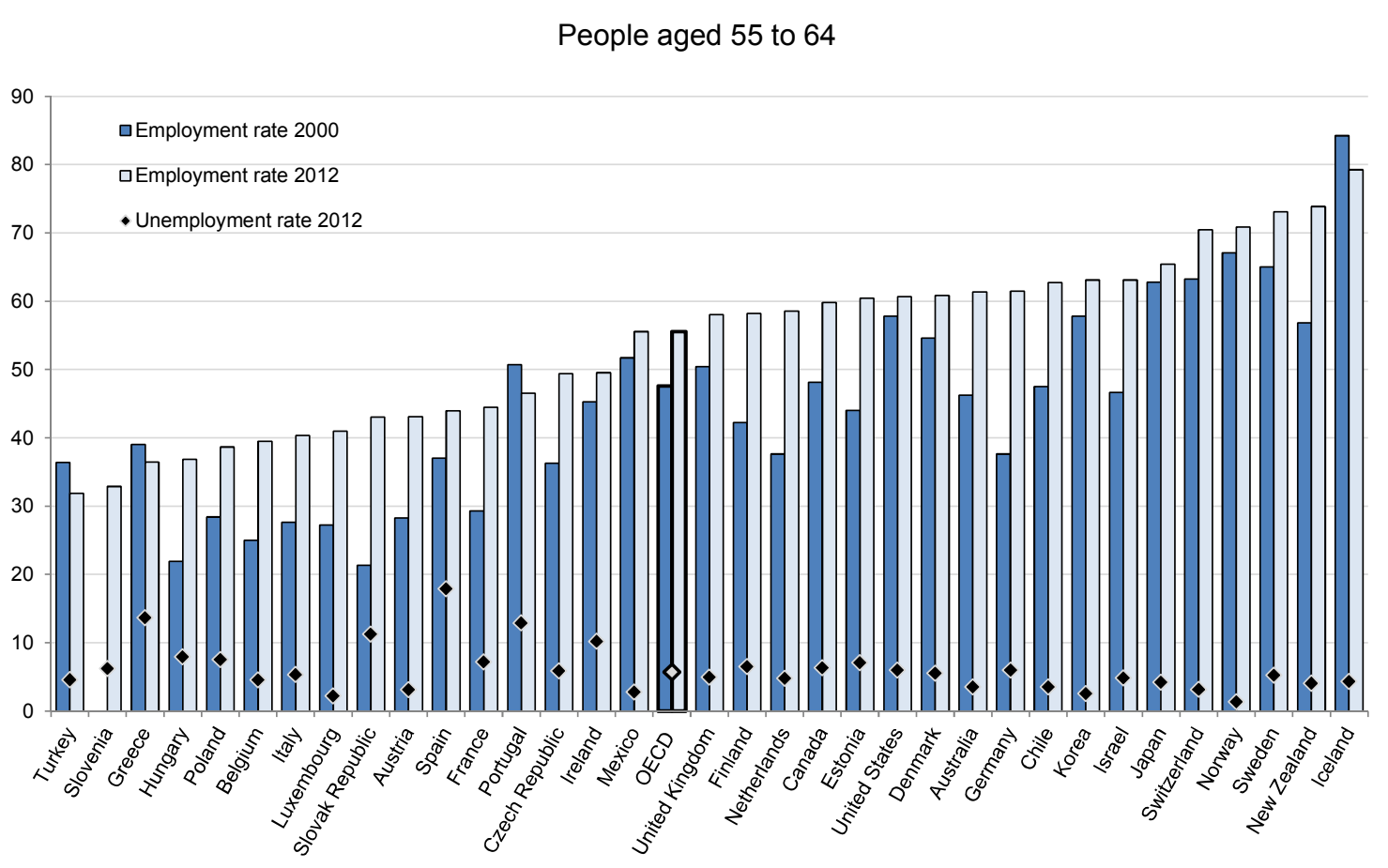

Source: OECD Labour force statistics (extracted 13 January 2014).

31. Regressions on the cyclicality of different social expenditures suggest that early retirement benefit spending increases by approximately half a per cent for a one per cent increase in unemployment. A decline in unemployment on the other hand does not lead to a reduction in early retirement spending. This indicates that substitution from unemployment to early retirement exists, and that this effect is indeed asymmetric. Early retirement schemes are being phased out in many OECD countries. Disability spending is not correlated with unemployment, but seems to increase with increasing GDP. The corresponding decrease in disability spending when GDP falls is not significant. This suggests that disability spending in the average OECD country is more of a structural, and less of a cyclical phenomenon. Hindering outflows to other benefits, that will often be associated with exiting the labour market permanently, can be done by making sure that other benefits are not overly generous compared to unemployment insurance, by effective gate-keeping for entrants into disability schemes and by closing routes to early retirement. While large and growing early retirement schemes are not a problem for most OECD countries any more, only a few countries have been able to curb disability spending (Figure 13). Countries have started to address some of the features responsible for the widespread granting of disability benefits. In particular, many countries are now making increasing efforts to identify and support people in using their remaining work capacity when determining benefit eligibility, rather than focusing solely on identifying disability. More should be done to implement better assessments of eligibility and periodic re-assessments, implementing activation policies and making sure that work pays for all recipients and applicants of disability benefits. 
Figure 13. Expenditure on unemployment insurance substitutes

Per cent of GDP

Panel A. Early retirement expenditure

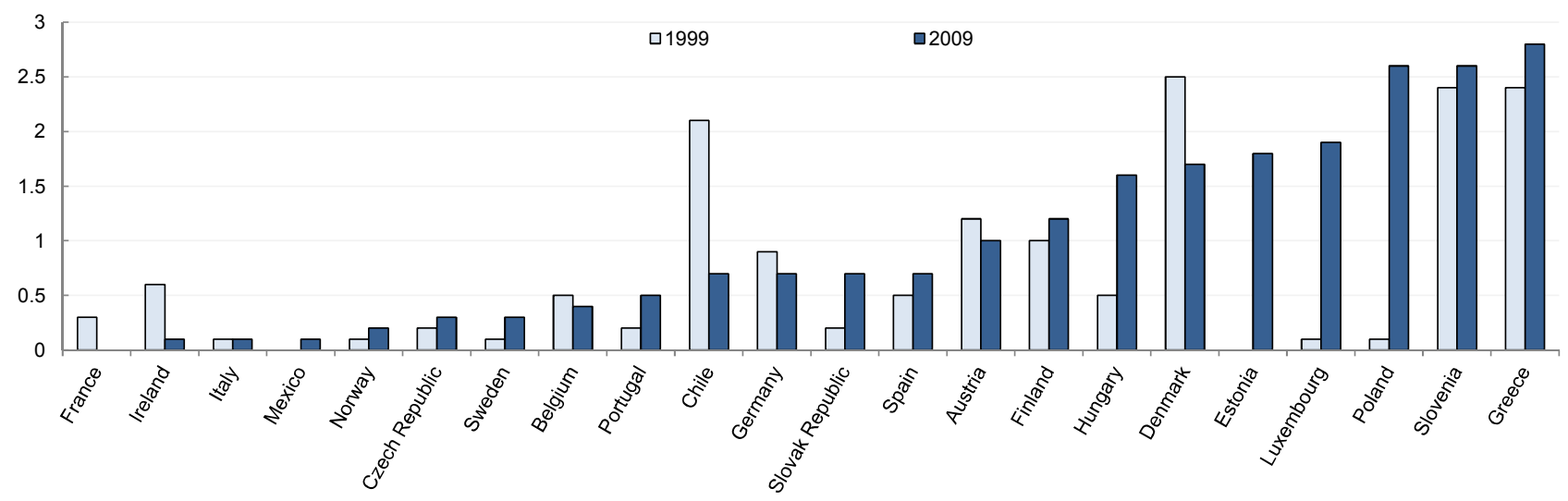

Panel B. Disability expenditure

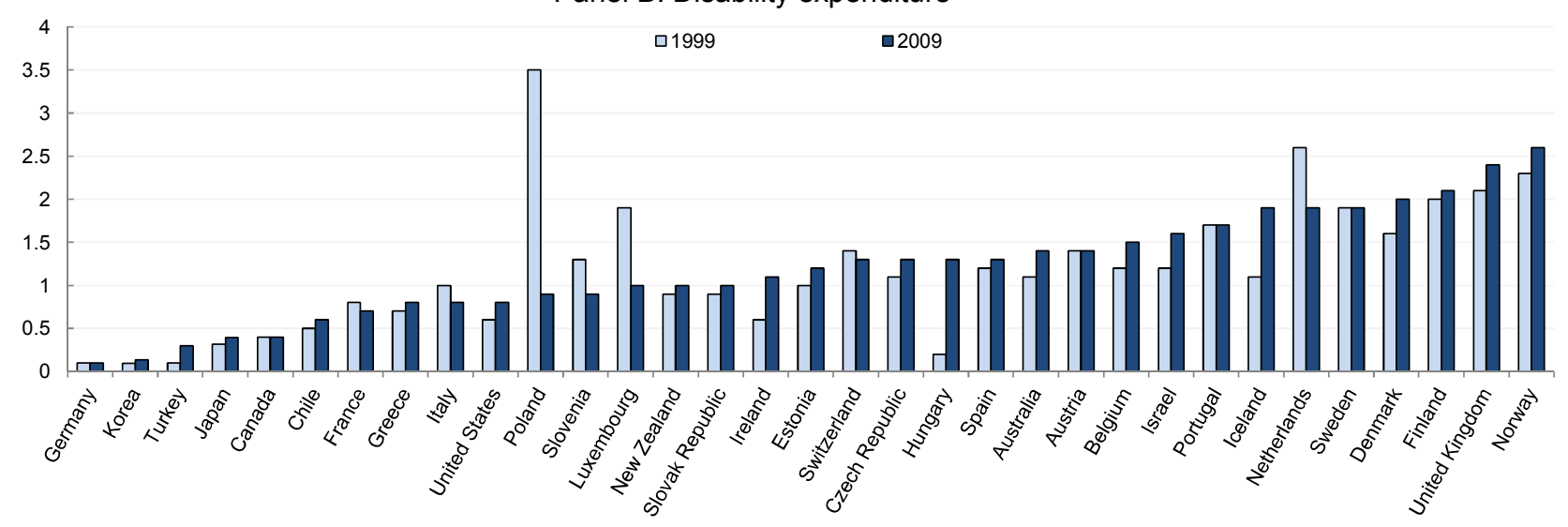

Source: The OECD Social expenditure database.

\section{Contingency planning}

\section{Healthy public finances - a cornerstone of the resilience of unemployment insurance schemes}

32. During times of crisis it is especially important that unemployment insurance can fulfil its aims of smoothing consumption and acting as an automatic stabiliser. Severe crises can pose significant stress to the unemployment scheme. The government bears the ultimate responsibility for the well-being of the unemployed, because private market mechanisms to insure against job losses are very rare, and moral hazard limits the scope for private insurance. This back-stop guarantee can be more or less explicit. Even in closed-loop unemployment insurance schemes where increased payments lead to a proportional increase in contributions, the government will in effect be the back-stop, either through social assistance for those who run out of eligibility, or by implicitly guaranteeing the unemployment insurance scheme against collapse. Spending should be contained in periods of economic expansion to build buffer funds to draw upon them in crises periods. Depending on the system design, governments could aim at a prudent government debt level to create fiscal space to cope with a crisis or they could build rainy day funds earmarked for unemployment insurance. Research on unemployment insurance reserve funds in American states show that earmarking of revenues for rainy day funds does not hinder politicians from dipping into such funds (Craig et al, 2013). Even though politicians are both risk averse and forward looking, they are at 
also impatient and time inconsistency issues arise. Earmarked funds also limit the risk pool and are hence less efficient than broader funds or fiscal space in general.

\section{Duration and generosity could be increased in times of need}

33. Temporary extensions of the maximum period of unemployment benefit receipt may have a useful role to play during a recession, especially in countries where the normal duration of these benefits is relatively low and access of the long-term unemployed to last-resort benefits such as social assistance is limited. There is some evidence that the generosity of unemployment insurance can increase as the unemployment rate rises, without detrimental effects, largely due to weaker job search externalities (De Serres et al., 2012; OECD, 2011), although this view is contested by e.g. Hagendorn et al. (2013). A weak labour market changes the considerations underpinning the design of unemployment insurance. The opportunity costs of education and training are lower, the expected returns to job search are lower, and the relevance of financial incentives to work may be somewhat lower when labour market demand is weak during a recession. These considerations may have a bearing on how unemployment insurance and active labour market policies could be adjusted during crises to best cater for future job prospects of the unemployed and at the same time fight poverty and raise the automatic stabilising effects of unemployment insurance. For the same reasons, higher replacement rates during crises in countries where replacement rates are low could also be warranted, as a tool to fight poverty and to smooth consumption for cashstrapped individuals. There are potential downsides to adjusting unemployment insurance generosity during downturns. Adjustments based on regional unemployment can for example reduce mobility. Such automatic links therefore need to be designed carefully. In Canada both eligibility criteria and duration of the unemployment benefit is adjusted automatically depending on the regional unemployment level. Such rules can also be found in some states in the United States. Israel implemented a state contingent easing of eligibility criteria during the recent downturn, triggered by an unemployment rate of $7.5 \%$. Changes to eligibility rules in Finland, France, Japan, Sweden and the United States since the onset of the crisis should make it easier for temporary or irregular workers to access benefits (OECD 2009). A number of countries increased the replacement rate for benefit recipients (e.g. Belgium, Finland, Greece and Turkey). Increases in the replacement rate in the Czech Republic and Poland were financed by reductions in the duration of benefits. In Australia, where unemployment benefits (Jobseekers Allowance) are means-tested, the asset test has been relaxed to make it easier to access benefits. The United States, Portugal and Iceland implemented discretionary policies to extend duration of unemployment insurance during the great recession. In the United States, several states have begun cutting benefit durations, sometimes significantly, and federal extensions expired at the end of 2013. However, because federal extensions are conditional on state benefit rules, they were also affected by cuts in individual states (OECD, 2014).

\section{Last resort assistance should be available to those in need on condition that they search for jobs}

34. After an initial fall as inflows of newly unemployed soar, long-term unemployment tends to shoot up during crises and with a slow recovery many individuals could lose their unemployment benefits. While this reduces the vulnerability of unemployment insurance schemes to shocks, this raises the vulnerability of those out of work. Social assistance payments are available in most OECD countries as a last resort for individuals who are not eligible to receive unemployment insurance, individuals who have lost eligibility during the unemployment spell, or as top-ups to the unemployment benefit to cover e.g. housing costs or living expenses in general (Immervoll, 2010). During severe crises, more unemployed individuals and their families will lose unemployment insurance eligibility, and depend on means-tested social assistance. Stringent means-testing is often applied to ensure that social assistance serves mainly the most vulnerable. As a result, typically self-supporting families who experience long-duration unemployment during a deep recession may encounter difficulties in accessing last-tier benefits or be obliged first to run down their savings or even sell their home, potentially jeopardising their long-term economic status. This suggests that it would be important to consider whether asset tests or other eligibility 
rules for these programmes are too strict for them to function effectively as a backstop to first-tier unemployment benefit programmes (OECD, 2011). Cutting individuals off from last resort financial assistance also has the negative effect that they are excluded from activation policies. The group which was most severely hit by the current crisis is youth. The young are afflicted by a high and rising prevalence of long-term unemployment and a disturbing rise in inactivity rates, and getting the young into jobs is more difficult when they are excluded from activation policies.

\section{Contingency plans to scale up activation policies should be in place}

35. When a crisis hits, there is a tension between ensuring financial soundness on the one hand and adequate income support for the unemployed on the other. Even though they are costly in the short term, effective activation policies with job search conditionality as the core make it possible to improve financial soundness with a minimum sacrifice of adequacy. They lower the cost borne by individuals who lose their jobs by more efficient matching and shorter unemployment spells. The costs for society are reduced by both higher activity and lower unemployment insurance expenditure (Bassanini and Duval, 2006; Andersen and Svarer, 2007; Andersen, 2013). Activation policies in some of the countries with the strongest rise in unemployment during the recent crisis have not been as responsive as required (Figure 11).

36. While conditionality should be kept as a cornerstone of active labour market policies also during recessions, some of the resources devoted to promoting and enforcing job search should instead be redirected towards education and training to increase future job prospects, since positive job search externalities are lower during downturns due to crowding-out effects (OECD, 2011). Several countries have increased the relative importance of training measures during the current downturn, while some countries where unemployment has increased drastically have moved in the opposite direction (Figure 14). There should be contingency planning in the active labour market policy administration to be able to scale up and train new employees when a crisis hits. 
Figure 14. ALMP spending on training was cut back in several crisis countries

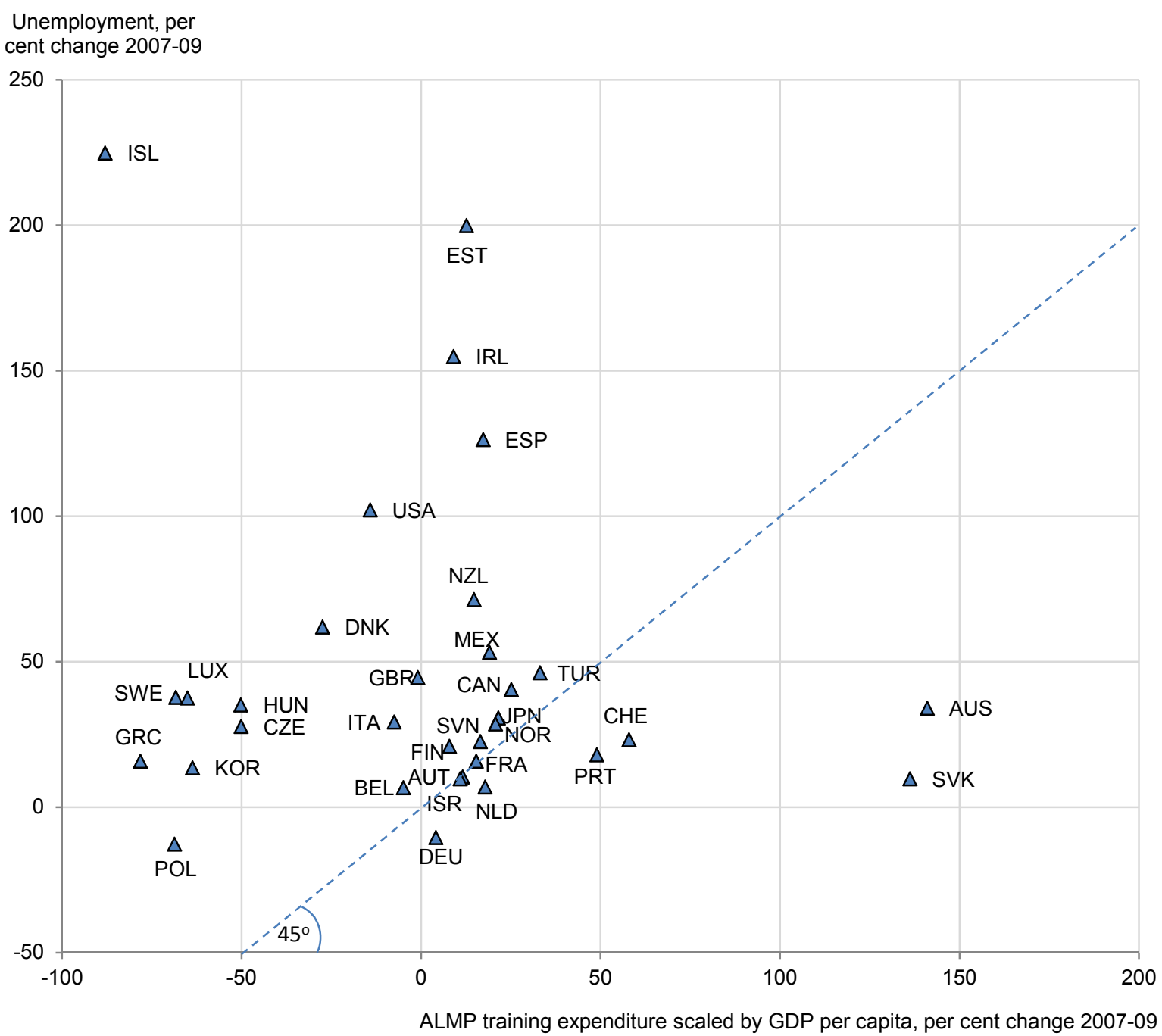

Note: ALMP spending on training as a share of total ALMP spending.

Source: OECD Social Expenditure database and EO93.

\section{Efficient and inclusive labour markets reduces unemployment insurance vulnerability}

37. How well unemployment insurance schemes can weather shocks depends on structural policies, since wage-bargaining institutions, employment protection legislation, taxes and regulations of product markets and services all affect both equilibrium unemployment and the volatility of unemployment and public revenues.

\section{Country profiles capture the various dimensions of unemployment insurance vulnerabilities}

38. Country profiles have been assembled in diamonds. The country profiles gather the major indicators for sustainability, adequacy and policy levers and allow comparisons with the OECD average. The dotted line represents the OECD average, the solid line and markers represent the country shown. When the solid line falls outside the OECD average this implies better results or, in the case of policy settings, higher generosity than the OECD average. Country profiles of Denmark and the United States are shown in Figure 15 and explained in Box 3 as an example. Country profiles for all OECD countries are provided in Appendix A2. 


\section{Box 3. Country profiles of unemployment insurance: The case of Denmark and the United States}

At $74 \%$, the initial replacement rate in Denmark is high compared with the OECD average. Together with duration and eligibility criteria on the OECD average, Denmark is a country with generous unemployment insurance benefits. At the same time, helped by extensive activation policies, the structural unemployment rate is relatively low and has not risen more than the OECD average during the latest recession. The level of spending is, however, close to the OECD average since unemployment benefits per person are high. With high coverage and high generosity, even small changes in unemployment can result in sharp changes in unemployment expenditure. Generous benefits lead to low poverty among the workless. More could be done to integrate immigrants in the labour market. Denmarks exposure to future GDP shocks is a bit lower than the OECD average.

In the United States temporary extentions of the unemployment insurance duration lead to duration reaching a peak of almost two years in 2011, which is still lower than the OECD average. The initial replacement rate of around $50 \%$ is low compared with the average. Even though eligibility criteria are less strict than in the OECD on average, the overall generosity of the scheme is low even when counting in the temporarty extension of duration. The share of the unemployed who were covered by unemployment insurance in 2008 is below the OECD average. The NAIRU is slightly above the OECD average, as is spending on unemployment insurance. The latter is affected by temporary benefit extensions and the choice of 2011 as the reference year. Immigrants in the United States are better integrated in the labour market than the OECD average.

Figure 15. Unemployment insurance indicators for Denmark and the United States Denmark United States

Policy levers

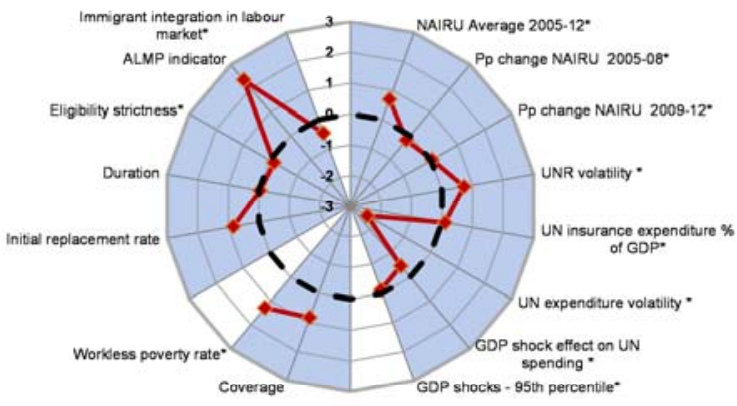

Policy levers

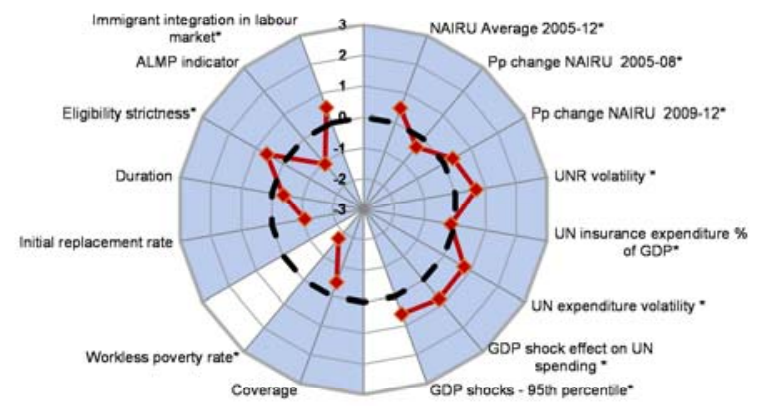

Adequacy

Adequacy

Note: The dotted line represents the OECD average, the solid line represents the country shown. Where the solid line falls inside the OECD average, the variable considered stands below the OECD average. For the "Policy options" indicators generosity is higher than the OECD average for observations above the dotted line. For the "Sustainability" and "Adequacy" indicators values are more favourable (e.g. NAIRU, volatility and poverty are lower and coverage is higher) the further the observation is removed from the centre of the diamond. The indicators are presented in units of standard deviation.

Legend:

Sustainability

NAIRU average 2005-12 = Average of structural unemployment rate

$\mathrm{Pp}$ change NAIRU 2005-08 = Change in percentage points between2005-08

$\mathrm{Pp}$ change NAIRU 2009-12 = Change in percentage points 2009-12

UNR volatility = Standard deviation of the unemployment rate (2000-12)

UN insurance expenditure \% of GDP = Unemployment insurance benefits as \% of GDP (2011)

UN expenditure volatility = Standard deviation of UN insurance expenditure as \% of GDP (1990-2012)

GDP shock effect on UN spending = Unemployment insurance benefits in \% of total wages, median projection 2050

GDP shock $-95^{\text {th }}$ percentile = Unemployment insurance benefits in $\%$ of total wages, the $95^{\text {th }}$ percentile projection 2050
Adequacy

Coverage $=$ Share of the unemployed entitled to unemployment benefits (200708)

Workless poverty rate $=\%$ of workless individuals with income below $50 \%$ of Policy options the median (2010)

Initial replacement rate $=$ Initial replacement rate in $\%$ of previous wage for an average of different family types and earnings

Duration = Benefit duration in years (2011)

Eligibility strictness $=$ Months of work, membership or equivalent earnings to gain eligibility to UI (2011)

ALMP indicator = ALMP expenditure per unemployed in $\%$ of GDP per capita (2010)

Immigrant integration in labour market $=$ Immigrant unemployment controlled for skills and country of origin, inverted 


\section{Key labour market policies have inconclusive effects on unemployment when seen in isolation}

39. Though the empirical literature is vast, there is no consensus on the quantitative impact of institutions on unemployment. ${ }^{7}$

- Standard economic theory and empirics suggests that high replacement rates with long duration reduce work incentives and increase unemployment (increase "moral hazard") (Moffitt, 1985; Meyer, 1990; Chetty, 2006). On the other hand, generous unemployment insurance provides better insurance coverage for workers, which provides an incentive to take riskier, productivityenhancing choices (Holzmann and Jørgensen, 2001), and high replacement rates could be positive for labour force participation (Andersen et al., 2007).

- If the poorer work incentives of generous unemployment insurance are counterbalanced by welldesigned active labour market policies, the negative effect can disappear completely (Bassanini and Duval, 2006).

- A number of empirical studies have found that high tax wedges increase unemployment, since higher gross wages reduce demand for labour and lower net wages reduce labour supply. The negative effect of tax wedges depends on: the labour market being imperfect with workers having some degree of market power and preferences for own wage over tax financed public services; and no institutional constraints to prevent shifting tax burdens onto wages.

- Trade unions and the structure of collective wage bargaining affect unemployment. The relationship is "hump-shaped". A highly decentralised bargaining system will ensure that workers get a wage close to their productivity. This is compatible with efficient use of labour and low unemployment. If wage setting centralisation is intermediate, that is if unions are strong enough to push wages above market-clearing levels, but too small and uncoordinated to internalise the detrimental effect on employment, labour market outcomes will be worse. If wage setting is highly centralised, wage bargaining will take into account adverse effects of wage setting on employment outcomes and ensure the competitiveness of exporting industries. In the latter case the wage distribution tends to be compressed, since unions need to defend their decisions to their members, and criteria such as equal pay for equal work or equal levels of education become important. Compressed wage distributions could act as a tax on low-productivity and a subsidy for high-productivity businesses, speeding up the pace of structural change and innovation (Barth and Moene, 2009). On the other hand, excessively compressed wages can also have negative effects, such as lower incentives to invest in human capital.

- There is no clear consensus about the effect of employment protection legislation on employment and unemployment rates, although there is broad agreement on other outcomes, such as labour mobility and productivity growth, which are both reduced by overly restrictive employment protection. Very unequal protection of permanent and temporary workers (duality) has been shown to have detrimental effects on labour market outcomes especially for youth (OECD, 2010), as is illustrated by the case of Spain (OECD, 2012a).

- Competition in product markets reduces unemployment. Entry of new firms increases activity and labour demand, while lower rents and an improved bargaining position by employers may reduce the gap between productivity and real wages that creates unemployment. In addition real

7. See Bassanini and Duval (2006 and 2009) for a literature overview. 
wages will be boosted via falling prices. Although loosening PMR will increase employment in the long run, this happens at the cost of higher wage inequality (OECD, 2013d).

40. It has been shown that the effect of a labour market policy reform depends on the settings of all other labour market policies, that any reform is complementary to all other reforms going in the same direction and that the more employment friendly the overall framework, the more effective reforms will be. If labour market policy settings are less employment friendly, reforms will be less effective and policy changes in the wrong direction will also have smaller negative effects (Bassanini and Duval, 2006).

41. In a literature review, Garda and Ziemann (2014) explore the relationships between labour market institutions and microeconomic stability. They find that both unemployment benefits, active labour market policies and more centralised and coordinated wage bargaining reduce earnings volatility. Taxes and transfers buffer household disposable income. Stricter product market regulations increase earnings volatility. Employment protection legislation reduces both inflows to and outflows from unemployment, with inconclusive effects on the unemployment level.

\section{Institutional settings and labour market and social outcomes}

42. The OECD Employment Outlook 2006 (OECD, 2006) showed with a Principal Component Analysis that countries can be clustered according to whether they use demand side interventions such as strict product market regulations and employment protection legislation more intensively or whether they use supply side interventions such as high unemployment replacement rates, strong union coverage and collective bargaining more intensively. ${ }^{8}$ While heavy dependence on demand side intervention was shown to generally reduce employment and increase unemployment rates, heavy dependence on supply side interventions were shown to be consistent with both good as well as bad labour market outcomes.

43. The analysis in the OECD Employment Outlook 2006 gave important lessons, and has been refined in this paper with more data, more countries and an extended time horizon. Some additional alterations have also been made. Most notably, principal components are derived without including the outcome variables (the employment and unemployment rate). This gives a pure analysis of policy settings. Outcomes are analysed separately. The collective bargaining indicator has been extended with additional information on the percentage of the workforce covered by collective bargaining. The new addition to the collective bargaining indicator has a $33 \%$ weight in the indicator, except if one of the two sources is missing, where the remaining source obtains $100 \%$ weight. One important feature of labour market settings is the coverage of unemployment insurance. ${ }^{9}$ Unfortunately, data are not readily available except for most EU countries and the United States, and unemployment benefits in per cent of pre-unemployment income (the replacement rate) have been used as a proxy for unemployment benefit coverage. Looking at the smaller sample of countries for which data on coverage are available, suggests that countries with high replacement rates also tend to have high coverage.

44. The clustering of policies offer additional insight compared to quantitative analyses, such as those of Bassanini and Duval. Bassanini and Duval's results show how marginal changes in individual labour market policies would affect labour market outcomes in a hypothetical country with labour market institutions equal to the OECD average, and does therefore not reflect the fact that most countries are far away from the average on most of the dimensions analysed. Using a two-dimensional plane is a way to group countries which share some key traits, and does not restrict the findings to the average OECD

8. This analysis included more countries and more variables than previous similar exercises (e.g. Sapir, 2006; Esping-Andersen, 1990).

9. Defined as the share of unemployed people who are receiving unemployment benefits. 
country. This analysis, which is more qualitative in nature, combined with insights of the effect of individual policy instruments and pair-wise combinations derived from analysis such as those of Bassanini and Duval, can provide useful information for policymakers about the scope for reform.

45. Various studies have shown that some countries have succeeded in creating an institutional setting where generous unemployment insurance and high economic efficiency is coupled with a good labour market performance, high income equality and well-managed public finances, while others are do less well along these dimnsions (e.g. Sapir, 2006 and Esping-Andersen, 1990). The reasons for these diverging outcomes are found not only in unemployment insurance settings, but also in other labour market policies, which are also important determinants of the vulnerability of unemployment insurance schemes to shocks. To uncover patterns of how different countries organise their labour markets, a principal component analysis has been carried out using data on the following six labour market institutions: the unemployment insurance replacement rate, the level of active labour market policy spending, the degree of collective bargaining, the income tax wedge, employment protection legislation and product market regulation (see Appendix A3 for a description of the data and sources). The principal component analysis is used to reduce the six input variables into two new variables (principal components) that capture as much as possible of the variation of the original dataset. ${ }^{10}$ These two principal components can be used to discover patterns, and they are interpreted according to their covariance with the original data. These two first components from the Principal Component Analysis explain $65 \%$ of the variance in the dataset. The features that separate the two factors are active labour market policy spending, unemployment benefit generosity and union coverage where the first component has a high score and the second factor has a large negative score, and product market regulation, where the second component has a high score and the first factor scores significantly lower. Furthermore, the second component is more correlated with strong employment protection legislation, while the first component is highly tilted towards high values of collective bargaining (Figure 16).

46. High values on the first component are consistent with having a strong reliance on unemployment insurance, collective bargaining and union coverage and supply side interventions such as ALMPs, while strong values on the second component are consistent with reliance on strict employment protection and product market regulations.

10. Principal component analysis is a mathematical procedure to convert a set of observations of possibly correlated variables into a set of linearly uncorrelated variables called principal components. The first component is constructed to account for as much of the variability in the data as possible, while the subsequent ones are constructed to account for as much of the residual variation as possible, being uncorrelated with preceding components. 
Figure 16. Labour market settings - factor composition

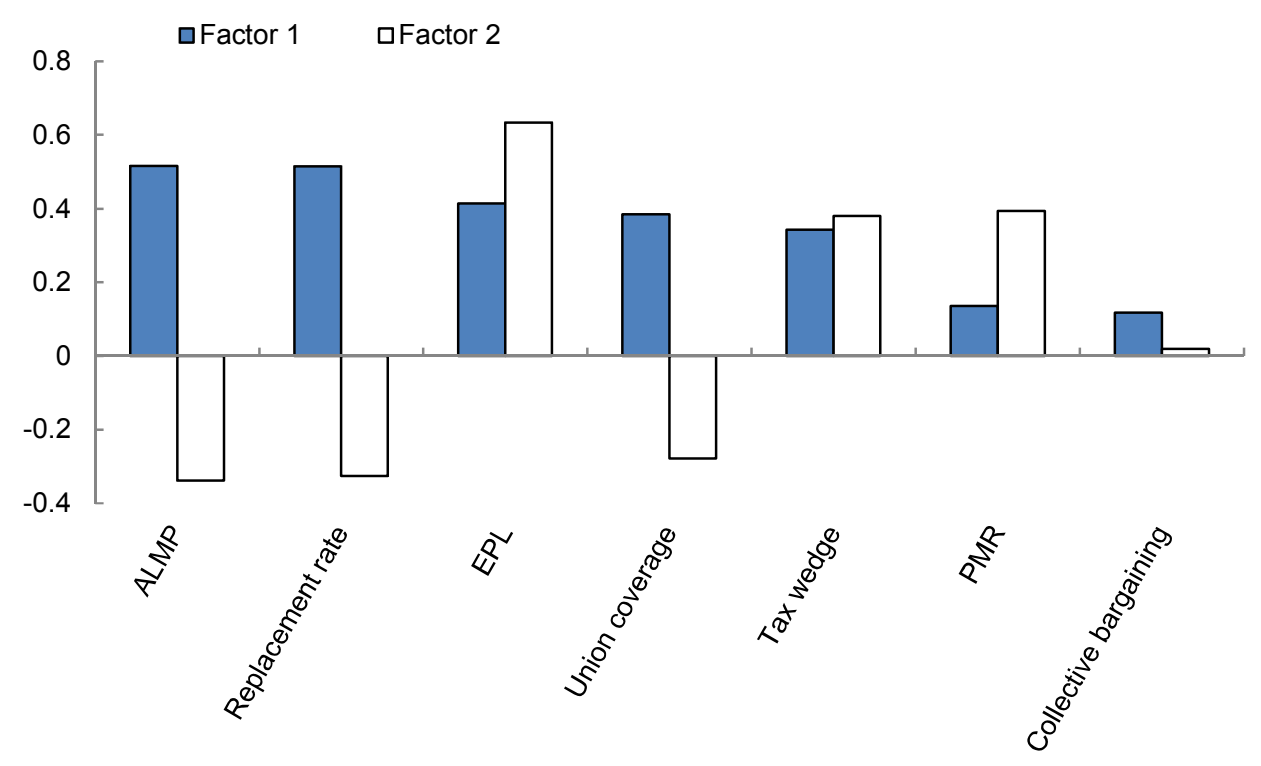

Note: Columns display the factor loadings for factor 1 and factor 2. Countries with a high score on a factor will generally have lower replacement rate, ALMP spending, and union coverage, and higher tax wedge, EPL and PMR (weighted by factor loadings) than countries with a lower score.

47. Doing a cluster exercise, four country clusters emerge that are quite similar to what is obtained elsewhere in the literature (Figure 17). ${ }^{11}$ The countries in the four different groups show some important differences in labour market settings and in efficiency outcomes as well as across equity indicators (Table 2). Both the cluster including the Nordics, Belgium and the Netherlands, and the mainly Englishspeaking cluster have higher employment and lower unemployment than the other groups. In addition, they show higher GDP per capita. Along the equity dimension, on the other hand, the English-speaking group shows the highest inequalities while the Nordics are on average the most egalitarian societies.

11. Compared with Esping-Andersen's original work (Esping-Andersen, 1990), most countries end up in the same grouping. For the purpose of this analysis, however, it is useful to further divide Esping-Andersen's "conservative" cluster in two, based on their placement along the axis of "reliance on social insurance and supply side interventions". 
Figure 17. A typology of labour market settings across the OECD

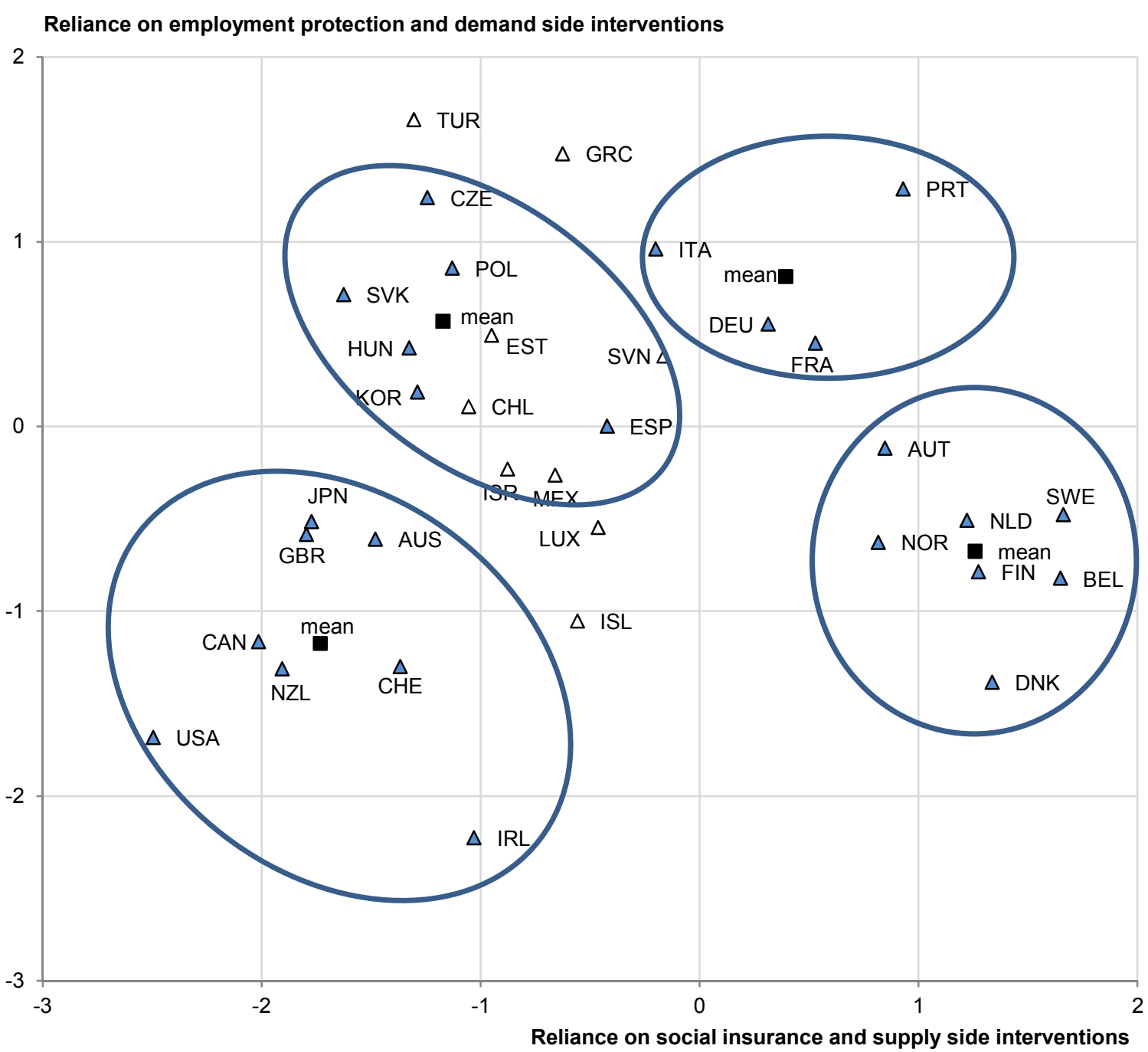

Note: The first two components of a principal component analysis of labour market institutions (triangles with fill). Data sources are described in Appendix A3. After the initial analysis, the factor loadings have been used to plot also those OECD countries where a balanced set of 2008 data were not available (triangles without fill). Missing variables for these countries are set to the average of all non-missing data for each variable.

48. Differences in labour market institutions help to explain differences in outcomes. A high degree of centralised wage bargaining, as in the Nordic countries, has been shown to both deliver economic efficiency at the macro level, and at the same time to deliver equality. High replacement rates combined with a higher prevalence of universal benefits also promote equality. Barth and Moene (2009) point to the existence of feedback effects between these two mechanisms, creating an "equality multiplier". Furthermore, a high level of active labour market policy spending per unemployed which is much higher than in the other countries neutralises the adverse incentive effects of high replacement rates (Bassanini and Duval 2006 and 2009), and further reduces negative outcomes of unemployment by helping individuals back into work. 
ECO/WKP(2014)27

Table 2. Labour market settings and outcomes

Levels, 2008

\begin{tabular}{|c|c|c|c|c|}
\hline & \multicolumn{2}{|c|}{ High employment outcomes } & \multicolumn{2}{|c|}{ Low employment outcomes } \\
\hline & $\begin{array}{l}\text { Mainly Anglo- } \\
\text { Saxon }\end{array}$ & Mainly Nordics & $\begin{array}{c}\text { Mainly } \\
\text { Continental and } \\
\text { Southern } \\
\text { Europe }\end{array}$ & $\begin{array}{l}\text { Mainly Eastern } \\
\text { Europe }\end{array}$ \\
\hline \multicolumn{5}{|l|}{ Incentives } \\
\hline Unemployment insurance replacement rate ${ }^{2}$ & 63.75 & 70.71 & 74.00 & 66.50 \\
\hline Coverage of unemployment insurance ${ }^{1}$ & 32.15 & 45.70 & 40.25 & 37.30 \\
\hline Tax wedge & 14.16 & 34.36 & 34.94 & 26.81 \\
\hline Active labour market policies ${ }^{2}$ & 9.14 & 32.67 & 18.61 & 10.56 \\
\hline \multicolumn{5}{|l|}{ Unionism } \\
\hline Union coordination indicator $^{2}$ & -0.3 & 0.54 & 0.41 & -0.20 \\
\hline Union density ${ }^{1}$ & 21.52 & 51.30 & 20.30 & 15.12 \\
\hline \multicolumn{5}{|l|}{ Regulation } \\
\hline Employment protection legislation ${ }^{2}$ & 1.23 & 2.35 & 3.04 & 2.37 \\
\hline Product market regulation ${ }^{2}$ & 0.95 & 1.08 & 1.21 & 1.31 \\
\hline \multicolumn{5}{|l|}{ Efficiency and labour market outcomes } \\
\hline Unemployment rate & 7.55 & 6.36 & 8.83 & 11.03 \\
\hline Employment rate & 58.93 & 58.22 & 51.79 & 50.55 \\
\hline GDP per capita (2005 dollars) & 37819 & 40213 & 30521 & 24529 \\
\hline \multicolumn{5}{|l|}{ Equality outcomes } \\
\hline Poverty rate after taxes and transfers & 10.97 & 6.50 & 8.66 & 7.96 \\
\hline In-work poverty rate & 6.30 & 4.28 & 5.87 & 6.15 \\
\hline Workless households & 10.28 & 6.96 & 7.78 & 6.54 \\
\hline Workless poverty rate & 57.57 & 36.01 & 41.86 & 31.60 \\
\hline
\end{tabular}

1. Coverage refers to the share of the unemployed that report that they are also eligible for unemployment benefits (Survey based). Union density refers to the share of wage and salary earners that are trade union members. Poverty rates refer to the $50 \%$ of the median income relative poverty rate.

2. Full data description with sources for these variables can be found in Appendix A2.

Source: Sources: Eurostat; OECD Labour Market Statistics; OECD Taxing Wages database; OECD Income Distribution database.

49. While the English-speaking countries display lower tax wedges and lower employment protection and product market regulations, the Nordics have tax wedges comparable with continental and southern Europe and somewhat lower regulations, especially in product markets. High tax wedges may still be compatible with high economic efficiency, if taxes are used in a way that promotes labour market participation and productivity, e.g. by providing universal access to education and affordable, high-quality childcare (Andersen et al., 2007). In addition, there is a higher prevalence of universal benefits, which improves work incentives at the lower end of the earnings distribution and increases public acceptance of taxes. Progressivity of taxes on high earnings is also relatively low in the Nordic countries, as the highest marginal income tax rate is reached at fairly low earnings (Paturot et al., 2013). While strict product market regulation is consistently shown to hamper growth, the effect of strict employment protection regulation on efficiency and labour market outcomes is less straight-forward. While regulations to ensure a clear rule-book and decent treatment of workers both while they are employed and when they are laid off are important, excessive risks and costs to employers laying off workers will reduce companies willingness to hire, especially in times of crises when future labour needs are the most uncertain. Labour market dualism, where insiders are overly protected by regulations (e.g. Spain), which is a prominent feature in 
many continental and southern European countries, has consistently been shown to be harmful for economic growth and employment outcomes especially for the young (OECD, 2010 and 2013c).

\section{Unemployment insurance in the BRIICS countries}

50. While the basic considerations underpinning decisions on unemployment insurance design are the same in the BRIICS as in OECD countries, there are reasons for emerging economies to choose different system designs (OECD, 2011). First, liquidity constraints among the poorest workers are likely to provide a major obstacle to sound labour market choices and economic choices in general (Holzmann and Jørgensen, 2001). The returns and positive externalities of better risk-management mechanisms for the poor can therefore be expected to be bigger in emerging economies than in the average OECD country. Second, the people that need unemployment insurance the most are often not eligible, but social assistance transfers can be a good alternative. Third, widespread informal employment combined with weak administrative capacity both imply low coverage of unemployment insurance and makes it possible to opt out of the unemployment insurance scheme by self-employment or informal employment.

\section{The case for improving social protection is strong}

51. Holzmann and Jørgensen (2001) argue that in addition to the common notion of social protection as a safety net, social protection should also be seen as a springboard to escape poverty. In their social risk management framework, social protection should not be seen as a cost, but rather as an investment. Such an investment in social protection is likely to have bigger returns the poorer the individuals who benefit from it for at least two reasons: First, poor individuals who face income losses can be forced to utilise costly coping mechanisms, depleting their productive capital by for example pulling children out of school, reducing nutritional intake or neglecting human capital accumulation. Second, because of the very dire consequences of income losses for the poor, risk aversion is likely to increase with poverty. The very poor are likely to be extremely risk averse and minimise the size of possible welfare losses. Individuals around the poverty line are more likely to minimise the probability of a loss in consumption below a given threshold, while individuals who are far removed from poverty are more likely to maximise the expected rate of return given a level of variability of returns (Holzmann and Jørgensen, 2001). Estimates for the agricultural sector in India indicate that this kind of income smoothing among the poorest individuals can reduce farm profits by $35 \%$ for the bottom wealth quartile (Binswanger and Rosenzweig, 1993).

52. Individuals for which the downside risk is not related to poverty and destitution, either because of higher income and wealth levels or because they are protected against adverse downside risks by social protection, are more likely to make sound labour market choices and economic choices in general. Evidence from the South African Child Support Grant show that the grant has had a more favourable impact on the labour market outcomes of the very poor than on less poor beneficiaries (OECD, 2011). Providing income support to job losers in Brazil in the form of unemployment benefits or severance pay reduces the pressure to accept job offers that involve large adjustment costs or do not match their qualifications, especially for those facing tight liquidity constraints (OECD, 2011).

\section{Unemployment insurance does not reach those who need it most}

53. Protection of the unemployed in emerging economies should hence be designed in a way that provides income support to those who because of liquidity constraints need it most, while also reducing informal work arrangements. Unemployment insurance does often not reach those who need it most. This is also the case for severance pay, which is an important part of unemployment compensation in emerging economies. In practice severance pay tends to be rather ineffective to compensate the most vulnerable job losers, since non-performance is widespread and severance pay is normally biased towards the better off. Unemployment insurance eligibility criteria necessitate a record of formal work ranging from 13 weeks in 
South Africa to 3 years in India, and access to severance pay depends on employment in the formal sector. In the emerging economies many of the poorest will not have the option of working in the formal sector and many individuals are self-employed in the informal sector (Figure 18). In Indonesia as many as $40 \%$ of the total employed are self-employed, while self-employment in the other emerging economies ranges between 20 and $30 \%$.

Figure 18. Informality is widespread in some emerging economies

Share of persons in informal employment in total non-agricultural employment, $2009^{1}$

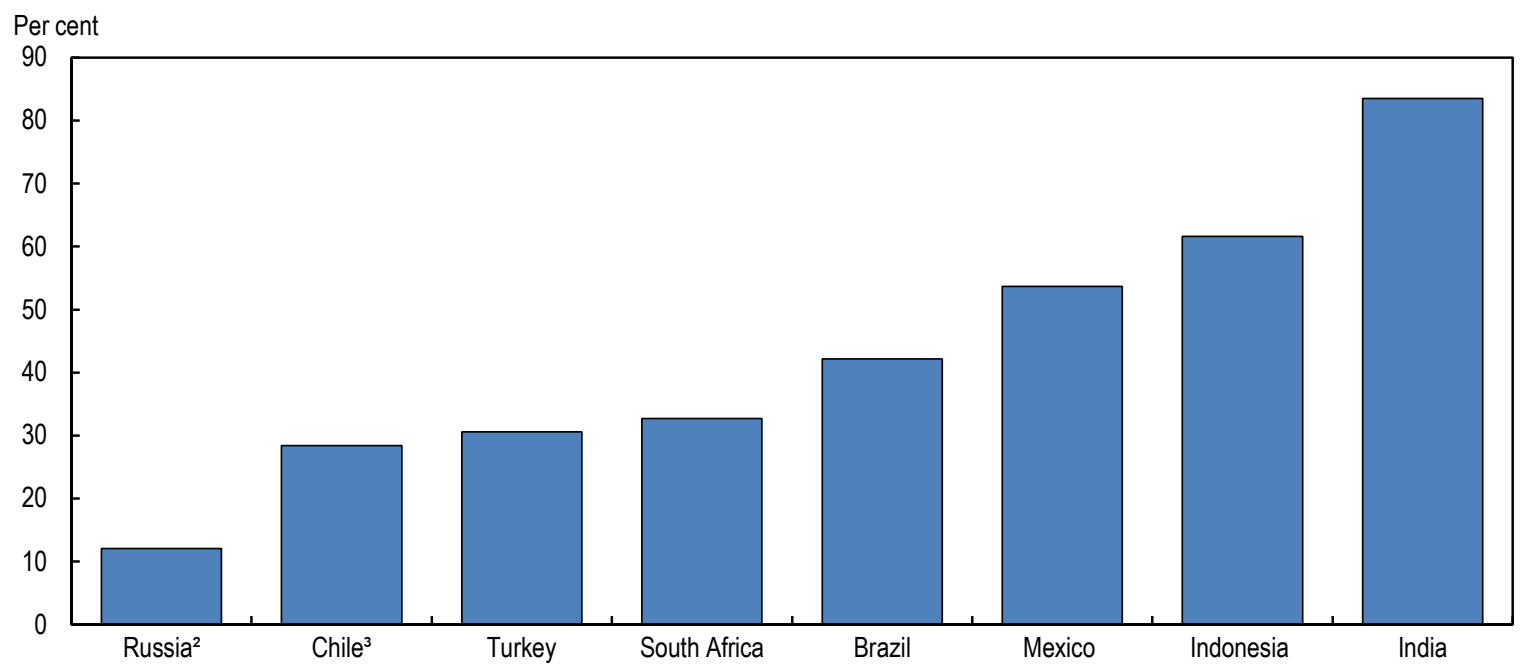

Note: Informal employment refers to total number of informal jobs, whether carried out in formal sector enterprises, informal sector enterprises, or households. Employment in the informal sector refers to all jobs in informal sector enterprises, or all persons who were employed in at least one informal sector enterprise, irrespective of their status in employment and whether it was their main or a secondary job.

1. Data refer to 2010 for the Russian Federation and South Africa and to 2005 for India.

2. Share of persons employed in the informal sector in total non-agricultural employment.

3. The share of self-employment in total employment is taken as a proxy for informality in the case of Chile because the most recent data on informal employment refer to the year 2000.

Source: ILO (International Labour Organisation) (2012); Key Indicators of the Labour Market (KILM) (Database).

54. The high incidence of informal employment and high minimum contributions leads to low rates of coverage of unemployment compensation in the BRIICS countries compared with the OECD average (Figure 19). Coverage is increasing with income, since the poorest are more likely to be in informal employment and less likely to meet contribution requirements. While people in the lowest earnings quintile are not at all covered by social insurance in Indonesia, 6\% are covered in Brazil and 19\% in South Africa. By comparison, coverage among the upper quintile is 35\% in Indonesia, $78 \%$ in Brazil and $86 \%$ in South Africa. 
Figure 19. Access to unemployment compensation

Panel A. Unemployment benefits and severance pay coverage (\% of unemployed)

$\square$ Advanced economies $\quad \square$ Emerging economies

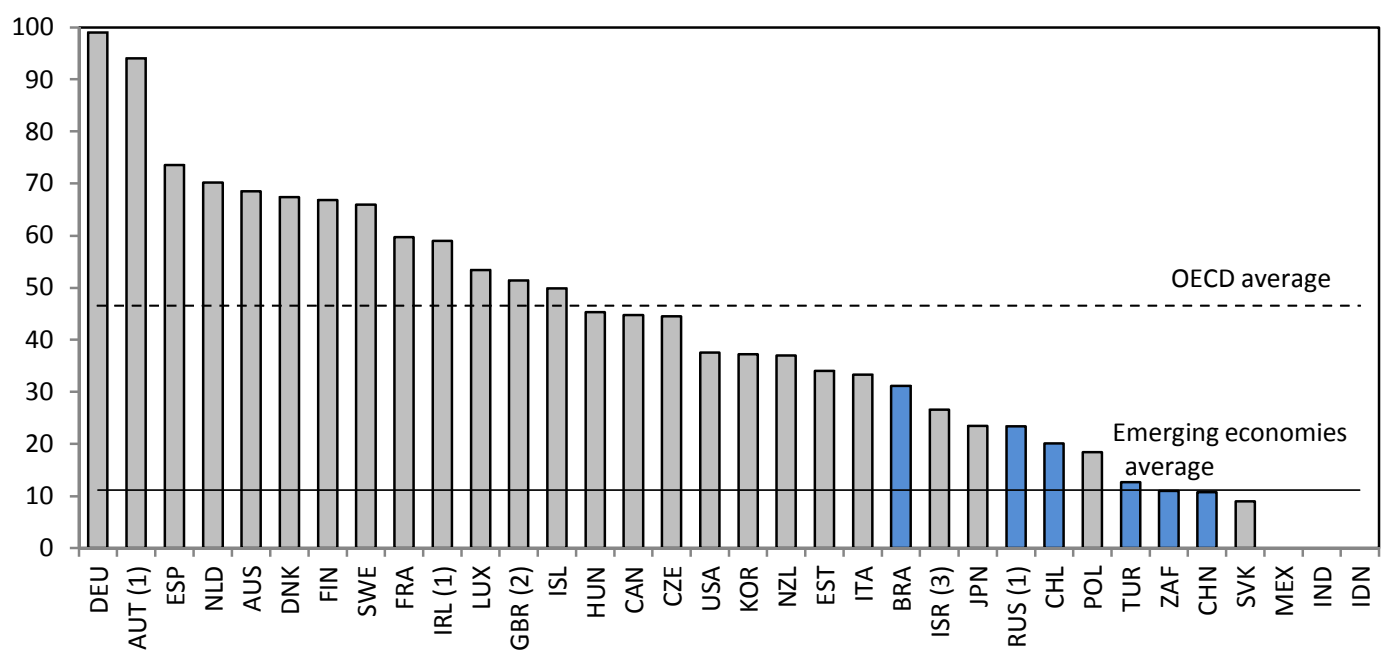

Panel B. Affiliation to social security by earnings quintile, latest available year

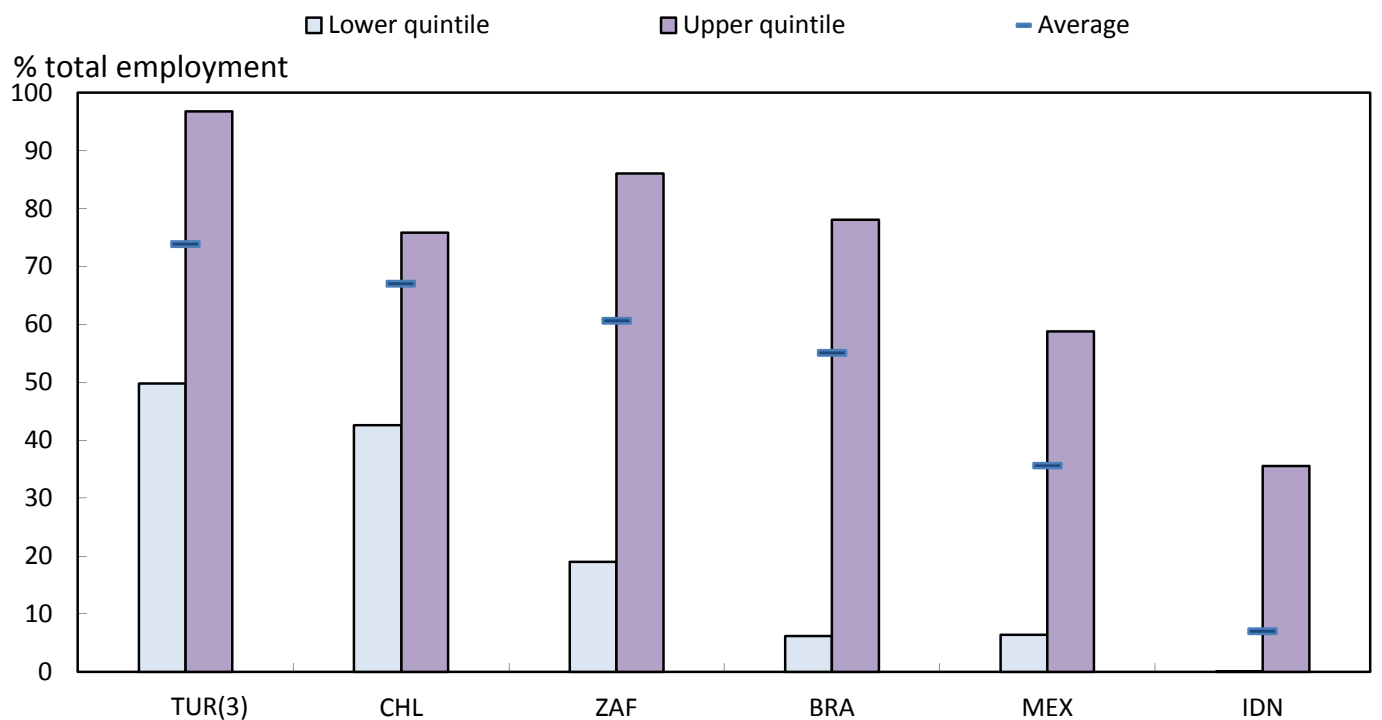

1. Data do not include unemployment assistance which exists in case the unemployed do not meet minimum eligibility conditions for UI or have exhausted the right to UI benefits.

2. Includes Jobseeker's allowance (social insurance and social assistance).

3. Data refer to salaried workers only

Source: OECD Employment Outlook 2011.

\section{Informality undermines unemployment insurance}

55. The BRIICS are not a homogeneous group when it comes to labour market institutions. Some important similarities nonetheless stand out. Tax wedges are generally low, social insurance expenditure is 
relatively low, product market regulations are tight, and institutions are generally weaker with more widespread corruption (Figure 20).

Figure 20. Labour market institutions in the BRIICS countries

Panel A. With low income tax wedges work incentives should be good

$\square 011 \quad \diamond 2008$

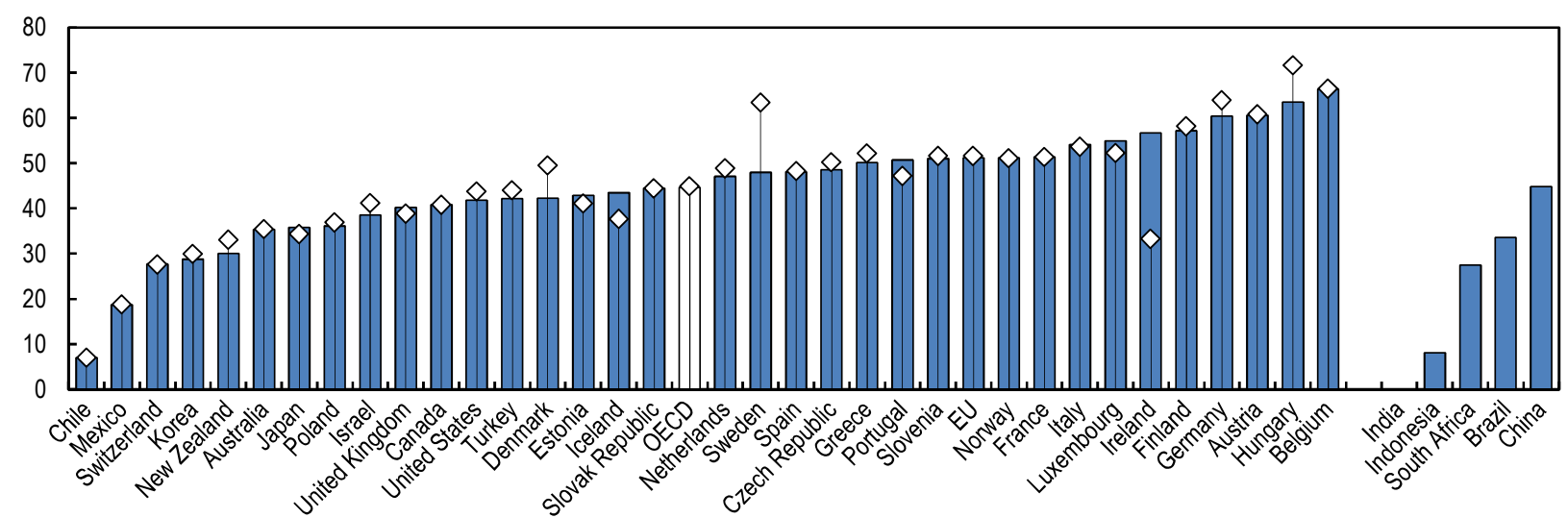

Panel B. Low administrative capacity and high corruption can pose problems for effective cash transfer programmes

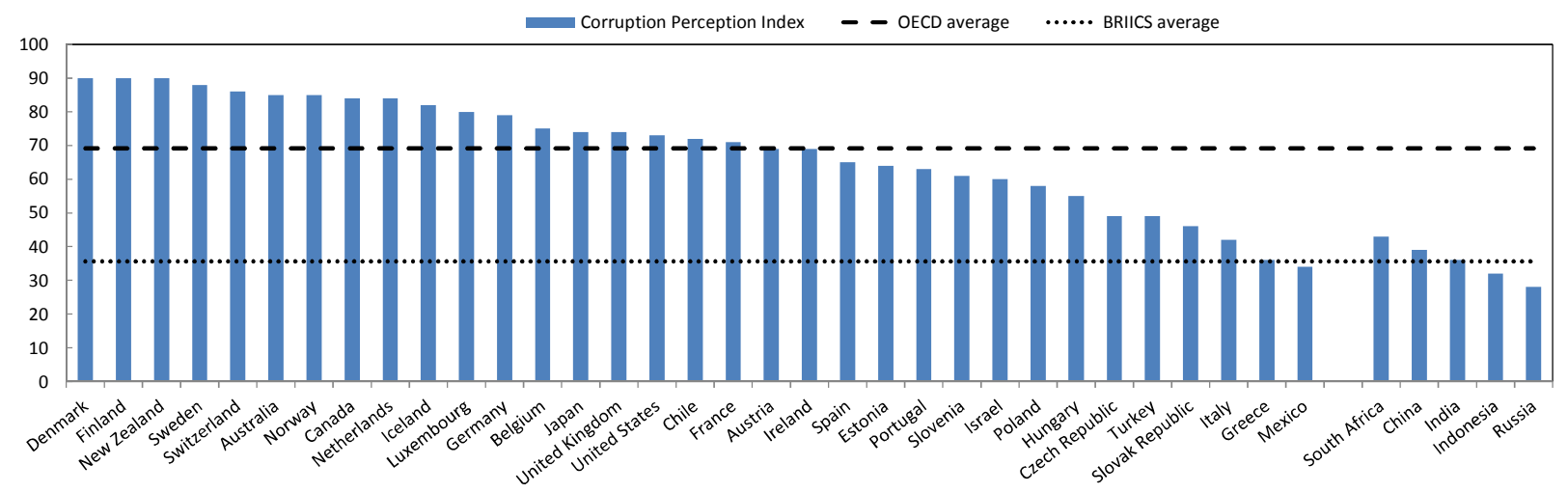

Note: Panel A: The data may not fully reflect the current situation in fast-reforming countries.

The tax wedge is measured as the difference between the change in total labour compensation paid by employers and the change in the net take-home pay of employees, as a result of an extra unit of national currency of labour income. The difference is expressed as a percentage of the change in total labour compensation. Data for Greece are for 2010. A solidarity tax was introduced in Greece in 2011 which would increase the tax burden compared to the previous year, and hence change its position regarding other OECD countries in 2011. Data refer to 2010 for the BRIICS countries except for Indonesia for which data refer to 2009. The value for India is zero in 2010. For India, the data refer to employees in the 95\% of companies in the manufacturing sector with less than ten employees. In firms with over 10 employees, the tax wedge would be no more than $5 \%$. In China, a significant portion of workers are not covered by the social security system and their tax wedge would be significantly lower than the figure reported here.

Panel B. Average country ranking over the 6 sub-indicators of the World Bank Governance Indicators, where 100 is the maximum score.

Source: Source: OECD (2012), Economic Policy Reforms 2012: Going for Growth; Taxing Wages Database; Gandullia, L., N. lacobone and A. Thomas (2012), "Modelling the Tax Burden on Labour Income in Brazil, China, India, Indonesia and South Africa"; OECD Taxation Working Papers, No. 14, the World Bank World Governance Indicators 2013 (WGI).

56. Reducing the high incidence of informality has been identified as a prime concern in the 2013 Going for Growth reform priorities for the BRIICS and lower-income OECD countries (OECD, 2013d). Labour utilisation is generally good in the BRIICS countries, except for South Africa and Turkey. While 
low tax wedges should encourage formal work, very high costs and strict procedures for dismissing permanent workers in China, India and Indonesia, high minimum wages in Indonesia and Brazil (OECD, 2013d), along with strict product market regulations in all BRIICS countries reinforce informality. Weak institutions and high corruption further complicate cash transfers in general, and conditional transfers in particular.

57. The high incidence of informality leads to a situations where unemployment insurance membership can be avoided by dependent work in the informal sector or by becoming self-employed. Selfemployment in emerging economies typically represents a form of informal employment. For the selfemployed, participation in social insurance is often not compulsory, and when it is, it tends to be difficult to enforce, leading to the same adverse selection problem as is the case with informal work.

58. Whether or not avoidance of unemployment insurance membership should be a concern depends on whether people end up in formal employment, informal dependent employment or as self-employed as a result of choice or a result of segmentation. If it is a result of choice, it means that the individuals who are least likely to need unemployment insurance see themselves better off opting out, while the individuals most at risk of unemployment opt for enrolment in the unemployment insurance scheme, undermining funding and increasing expected payments per covered individual.

59. Most studies on OECD emerging economies and BRIICS countries conclude that segmentation does exist (OECD, 2011). Informal workers generally would prefer working in the formal sector, but are only able to obtain work in the informal sector. The self-employed on the other hand, are older, more educated and more likely to hold collateral, and movement from formal work to self-employment is to a much higher degree voluntary. In other words, the possibility of opting out does exist for this group of people, but to which degree the unemployment insurance contribution is the decisive factor in an individual's decision to become self-employed is an open question. In countries with ambitions to expand social insurance, the possibility of social insurance arbitrage by going from formal work to selfemployment should nonetheless be closed, and formal work should be made more attractive as compared to informal employment.

60. A related, but different question is to which extent the existence of a large informal sector leads to fraud by workers working in the informal sector while at the same time collecting unemployment benefits. Except for the cost and efficiency loss of collecting contributions this is harmful only to the extent it leads to moral hazard (people quitting their job to collect two incomes), since it is a cash transfer which is also limited in duration. Such an extra cash boost could even be positive for growth to the extent it redistributes resources from the more to the less well off, and hence reduces liquidity constraints and provides the means to engage in productive activity. Widespread fraud does, however, run the serious risk of undermining the legitimacy of the system, and the possibility for such fraud should be limited as much as possible. This would be done most effectively by increasing formality. 
ECO/WKP(2014)27

\section{BIBLIOGRAPHY}

Andersen, T. et al. (2007), The Nordic Model: Embracing Globalisation and Sharing Risks, The Research Institute of the Finnish Economy (ETLA), Taloustieto Oy, ISBN 978-951-628-468-5.

Andersen, T. M. and M. Svarer (2007), "Flexicurity - Labour Market Performance in Denmark", CESifo Economic Studies.

Andersen, T.M. (2013), “Collective Risk Sharing: The Social Safety Net and Employment”, (forthcoming).

Barth, E. and Moene, K. O. (2009), “The Equality Multiplier”, NBER Working Paper, No.15076.

Bassanini, A. and R. Duval (2006), "Employment Patterns in OECD Countries: Reassessing the Role of Policies and Institutions", OECD Social, Employment and Migration Working Papers, No. 35, OECD Publishing, Paris.

doi: $10.1787 / 702031136412$

Bassanini, A. and R. Duval (2009), "Unemployment, Institutions, and Reform Complementarities: Reassessing the Aggregate Evidence for OECD Countries", Oxford Review of Economic Policy, Vol. 25, No. 1.

Binswanger, H. and M. Rosenzweig (1993) "Wealth, Weather Risk and the Composition and Profitability of Agricultural Investments", Economic Journal, 103, 56-78.

Boeri, T., and H. Bruecker (2011), "Short-time Work Benefits Revisited: Some Lessons from the Great Recession”, Economic Policy, Vol. 26, No. 68, pp. 697-765.

Braconier, H. and Westmore, B. (2014), “OECD@100: Policies for a Shifting World”, OECD Economics Department Working Papers, OECD Publishing, Paris, forthcoming.

Craig, S.G., W. Hemissi, S. Mukherjee, and B.E. Sørensen (2013), "How Do Politicians Save? Buffer Stock Management of Unemployment Insurance Finance", CEPR Discussion Paper, No. DP9520.

Chetty, R. (2006), "A General Formula for the Optimal Level of Social Insurance”, Journal of Public Economics, Vol. 90, pp. 1879-1901.

De Serres, A., F. Murtin and C. de la Maisonneuve (2012), "Policies to Facilitate the Return to Work", Comparative Economic Studies, No. 54, pp. 5-42

European Council (2013), “On Establishing a Youth Guarantee”, Council Recommendation of 22 April 2013, 2013/C 120/01.

Esping-Andersen, G. (1990), The Three Worlds of Welfare Capitalism, Cambridge: Polity Press.

Garda, P. and V. Ziemann (2014), "Economic Policies and Microeconomic Stability: A Literature Review and Some Empirics", OECD Economics Department Working Paper, No. 1115, OECD Publishing, Paris. 
Hagedorn, M., F. Karahan, I. Manovskii, and K. Mitman (2013), "Unemployment Benefits and Unemployment in the Great Recession: The Role of Macro Effects", NBER Working Paper, No. 19499.

Hollyday, FBM (1970), Bismarck, Great Lives Observed, Prentice-Hall.

Holzmann, R. and Jørgensen, S. (2001) "Social Risk Management: A New Conceptual Framework for Social Protection, and Beyond", International Tax and Public Finance, 8, 529-556.

Immervoll, H. et al. (2010), "Distributional Consequences of Labor Demand Adjustments to a Downturn: A Model-Based Approach with Application to Germany 2008-09", OECD Social, Employment and Migration Working Papers, No. 110, OECD Publishing. doi: 10.1787/5km68fvs7gzt-en

Immervoll, H. (2010), "Minimum Income Benefits in OECD Countries: Policy Design, Effectiveness and Challenges", OECD Social, Employment and Migration Working Papers, No. 100, OECD Publishing. doi: 10.1787/218402763872

Immervoll, H. (2012) "Reforming the Benefit System to 'Make Work Pay': Options and Priorities in a Weak Labour Market", IZA Policy Paper No. 50

Martin, J. P. (2000), "What Works among Active Labour Market Policies: Evidence from OECD Countries' Experiences", OECD Economic Studies, No. 30, 2000/I.

Meyer, B. (1990), "Unemployment Insurance and Unemployment Spells", Econometrica, Vol. 58 (July), pp. 757-782.

Moffitt, R. (1985), "Unemployment Insurance and the Distribution of Unemployment Spells", Journal of Econometrics, 28, 85-101.

OECD (1994), The OECD Jobs Study: Facts, Analysis, Strategies, OECD Publishing, Paris.

OECD (2006), OECD Employment Outlook 2006: Boosting Jobs and Incomes, OECD Publishing Paris.

OECD (2007), OECD Employment Outlook 2007, OECD Publishing, Paris. doi: 10.1787/empl_outlook-2007-en.

OECD (2009), "Addressing the Labour Market Challenges of the Economic Downturn: A Summary of Country Responses to the OECD-EC Questionnaire", OECD Publishing, Paris, available online only at www.oecd.org/dataoecd/15/29/43732441.pdf.

OECD (2010), Off to a Good Start, Jobs for Youth, OECD Publishing, Paris.

OECD (2011), OECD Employment Outlook 2011, OECD Publishing, Paris.

OECD (2012a), OECD Economic Surveys: Spain 2012, OECD Publishing, Paris.

OECD (2013a), OECD Economic Outlook, Vol. 2013/1, OECD Publishing, Paris.

OECD (2013b), OECD Employment Outlook 2013, OECD Publishing, Paris.

doi: 10.1787/empl_outlook-2013-en 
OECD (2013c), OECD Economic Surveys: Belgium 2013, OECD Publishing, Paris. doi: 10.1787/eco_surveys-bel-2013-en

OECD (2013d), Economic Policy Reforms 2013: Going for Growth, OECD Publishing, Paris.

OECD (2014), Society at a Glance 2014: OECD Social Indicators, OECD Publishing. doi: 10.1787/soc_glance-2014-en

Paturot, D., K. Mellbye and B. Brys (2013), “Average Personal Income Tax Rate and Tax Wedge Progression in OECD Countries”, OECD Taxation Working Papers, No. 15, OECD Publishing, Paris.

Sapir, A. (2006), "Globalization and the Reform of European Social Models." JCMS: Journal of Common Market Studies, 44: 369-390. doi: 10.1111/j.1468-5965.2006.00627.x

Venn, D. (2009), "Legislation, Collective Bargaining and Enforcement: Updating the OECD Employment Protection Indicators", OECD Social, Employment and Migration Working Papers, No. 89, OECD Publishing, Paris.

doi: $10.1787 / 223334316804$ 


\section{APPENDIX A1}

61. To assess the sensitivity of long-term projections to shocks to the determining variables, studies often rely on Monte Carlo simulations. They treat one or more of the variables affecting the outcome of interest as stochastic. Stochastic shocks to the variables that determine unemployment insurance spending, such as GDP, generate a distribution of unemployment insurance expenditure at each point in time of the projection period.

62. Monte Carlo simulations of empirical models are done in three steps: 1) a statistical model is fitted to each stochastic determining variable whose residual then represents the stochastic shock; 2) the residuals or shocks are assumed to be generated by a statistical distribution; in Monte Carlo simulations the normal distribution is often used; 3 ) a random number is generated from this statistical distribution, which, representing a shock, is fed into the stochastic input variable's projection, which in turn affect the outcome of interest - unemployment insurance spending in this case. Repeating step three a large number of times for all periods of the projection horizon, yields a distribution for the outcome of interest. This distribution can then be used to evaluate the future vulnerability of unemployment insurance expenditure to shocks. A wide dispersion of the distribution around the projected central value would suggest that the outcome is highly vulnerable to shocks.

63. The results shown in Figure 5 in the paper treat GDP as the only stochastic variable. The shocks to GDP (step 1 above) were extracted from fitting past output gaps with a time-series model. These shocks reflect temporary deviations of GDP from its potential.

64. As concerns step two, this study departs from the normality assumption regarding the distribution of shocks. This assumption is likely to be excessively restrictive for the purpose of this exercise as it implies an exceedingly small probability of observing shocks of the magnitude experienced in 2008 and 2009. Formal statistical tests of the residuals of the estimated statistical models fitting the output gap indeed reject for most countries the null hypothesis of normally distributed residuals. Plotting the kernel distribution densities of the shocks it is possible to show that for many countries they are indeed highly asymmetric, have fat tails as extreme outcomes (i.e. often large negative ones) are more frequent than what the normal distribution predicts. The null hypothesis that the residuals are independently distributed - that is, the value of a shock does not depend on the value of past shocks - is not rejected, lending support to the statistical model used to fit output gaps.

65. This work then relies on bootstrap rather than Monte Carlo methods. Instead of generating random numbers assuming a normal distribution, bootstrap techniques involve re-sampling shocks from their actual distribution - that is the distribution of the statistical model's residuals. 


\section{APPENDIX A2 - COUNTRY PROFILES}

Australia

Policy levers

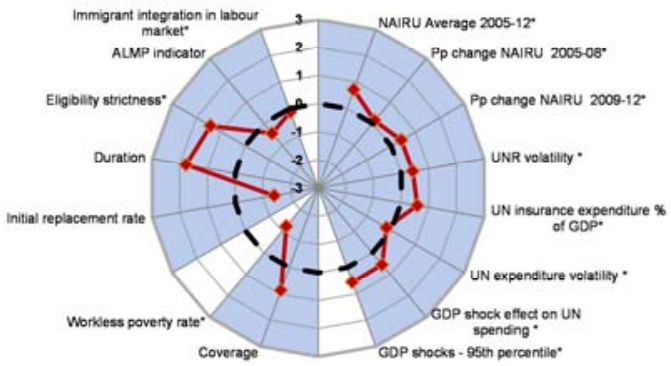

Adequacy

Belgium

Policy levers

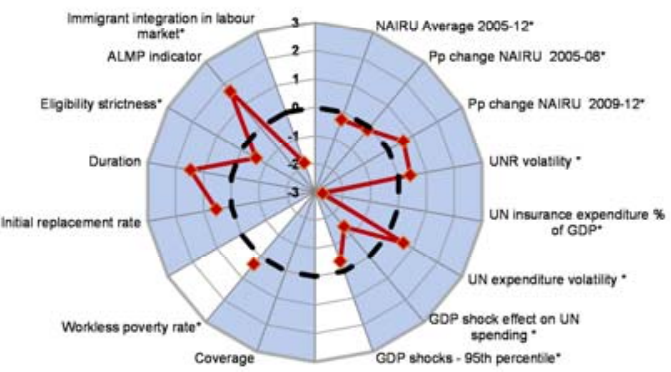

Adequacy

Chile

Policy levers

Sustainability

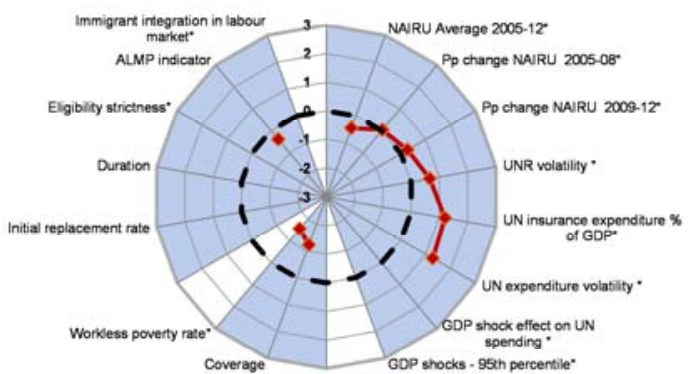

Adequacy
Austria

Policy levers

Sustainability

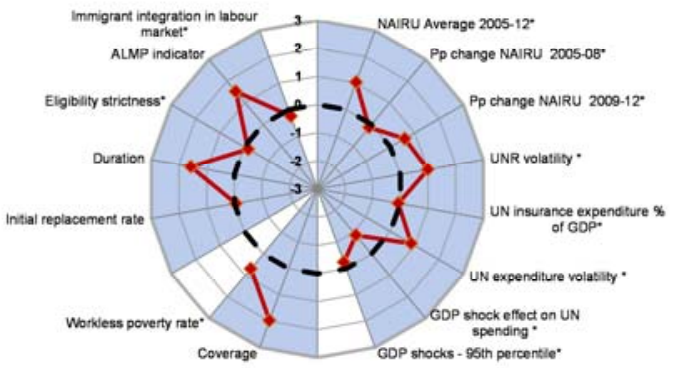

Adequacy

Canada

Policy levers

Sustainability

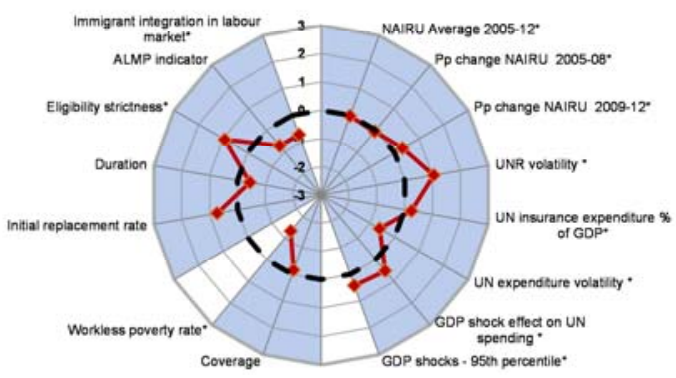

Adequacy

Czech Republic

Policy levers

Sustainability

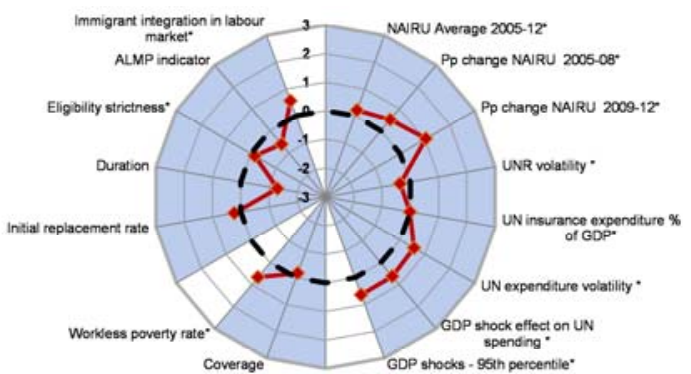

Adequacy 
ECO/WKP(2014)27

COUNTRY PROFILES (cont'd)

Denmark

Policy levers
Sustainability

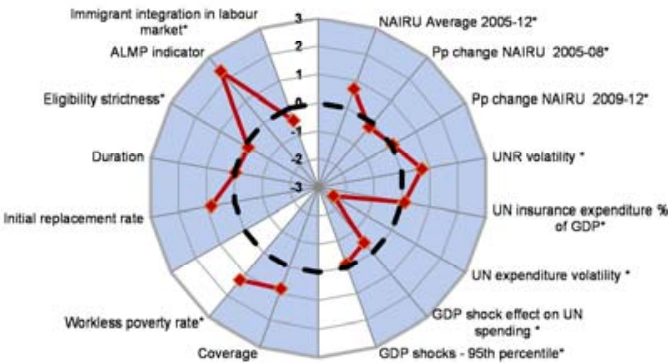

Adequacy

Finland

Policy levers

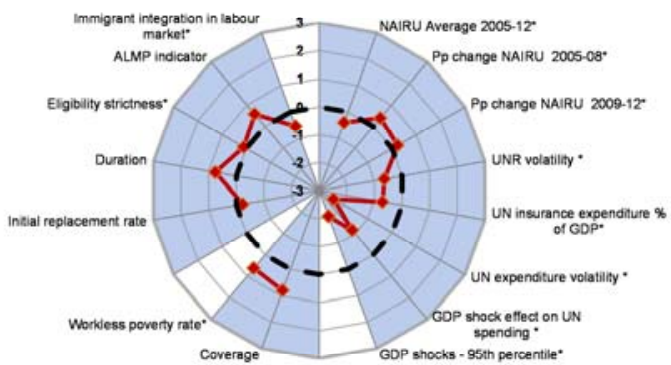

Adequacy

Germany

Policy levers

Sustainability

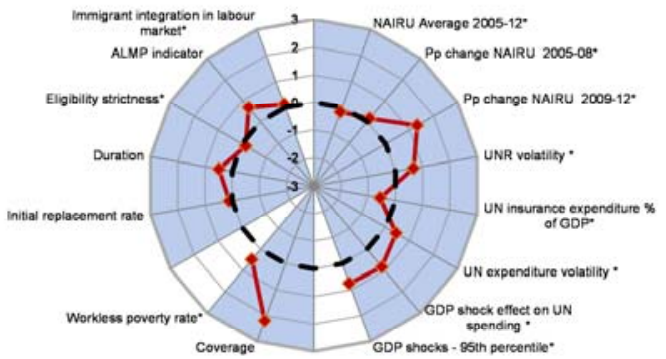

Adequacy
Estonia

\begin{tabular}{l} 
Policy levers $\quad$ Sustainability \\
\hline
\end{tabular}

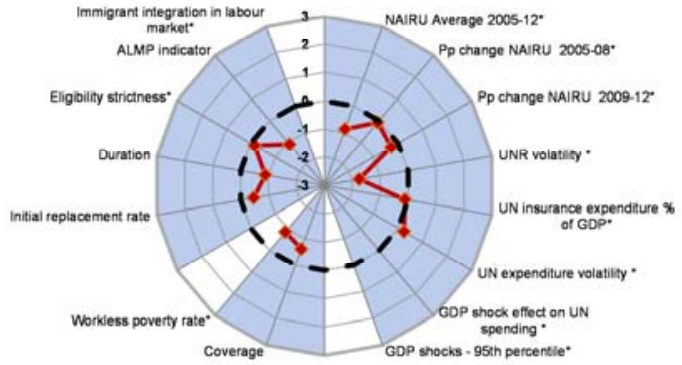

Adequacy

France

Policy levers

Sustainability

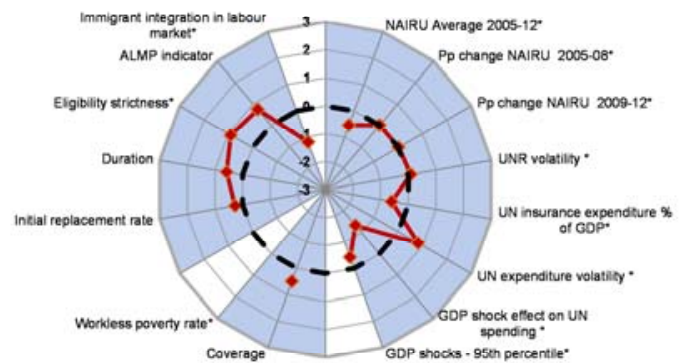

Adequacy

Greece

Policy levers

Sustainability

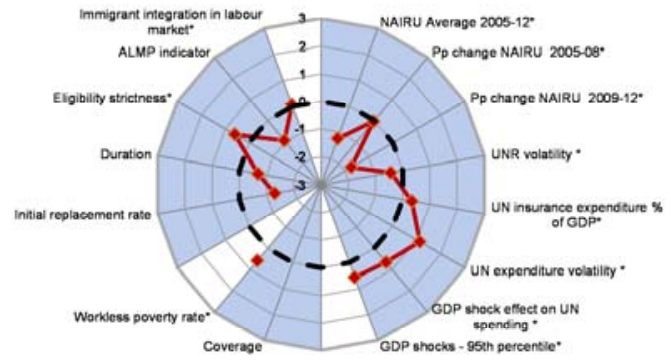

Adequacy 
ECO/WKP(2014)27

\section{COUNTRY PROFILES (cont'd)}

Hungary

Policy levers

Sustainability

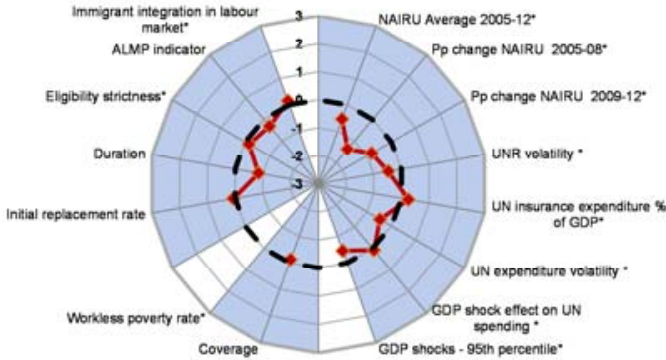

Adequacy

Ireland

Policy levers

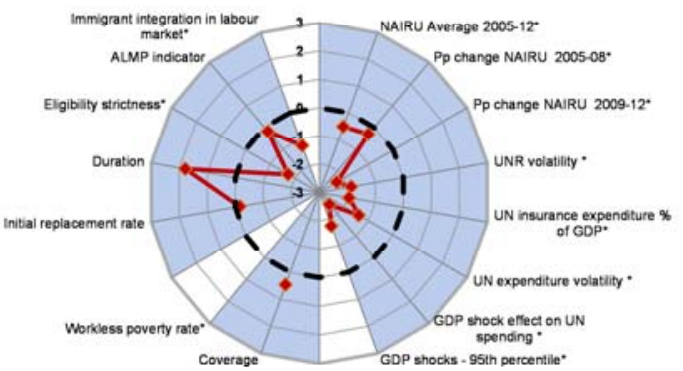

Adequacy

Italy

Policy levers

Sustainability

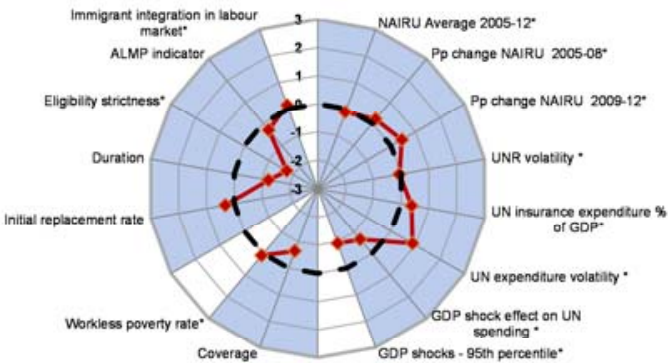

Adequacy
Iceland

Policy levers

Sustainability

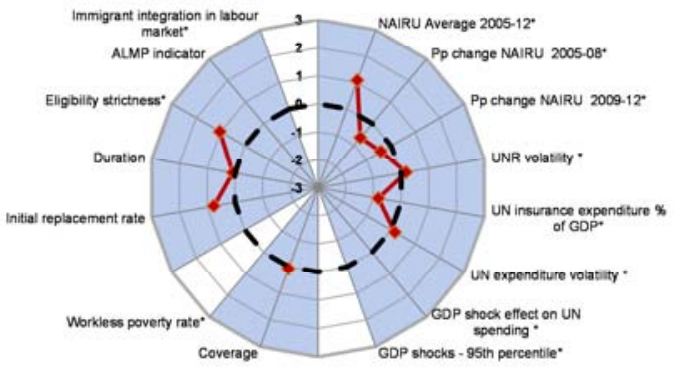

Adequacy

Israel

Policy levers

Sustainability

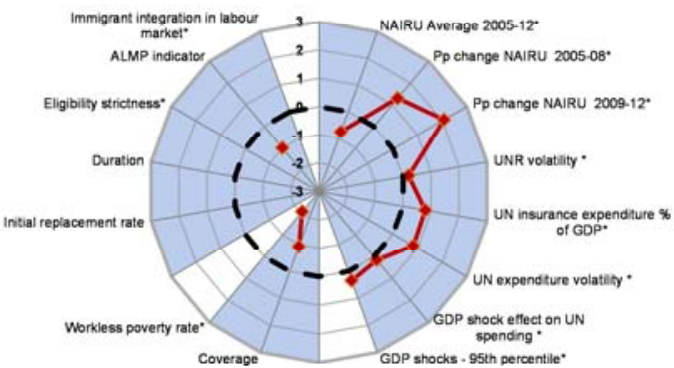

Adequacy

Japan

Policy levers

Sustainability

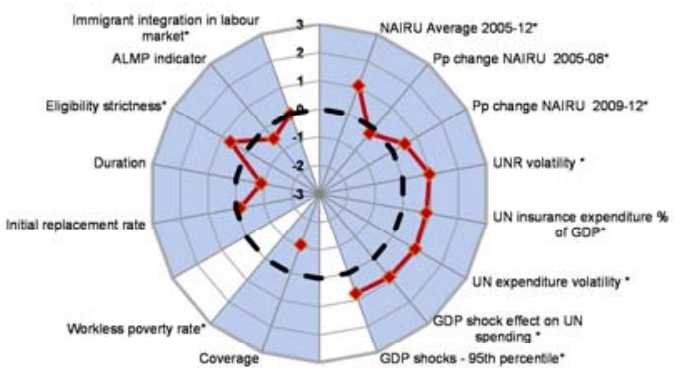

Adequacy 
ECO/WKP(2014)27

COUNTRY PROFILES (cont'd)

Korea

Policy levers

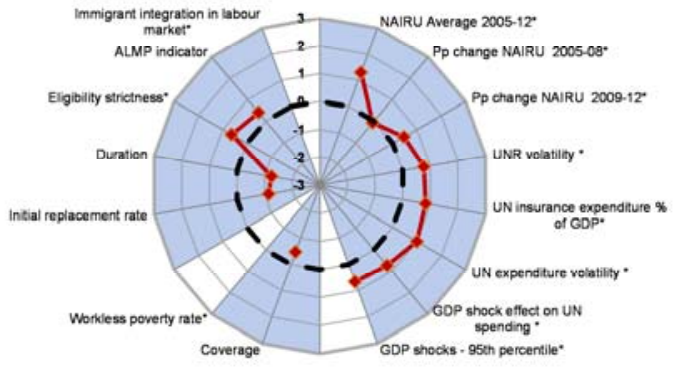

Adequacy

Mexico

Policy levers

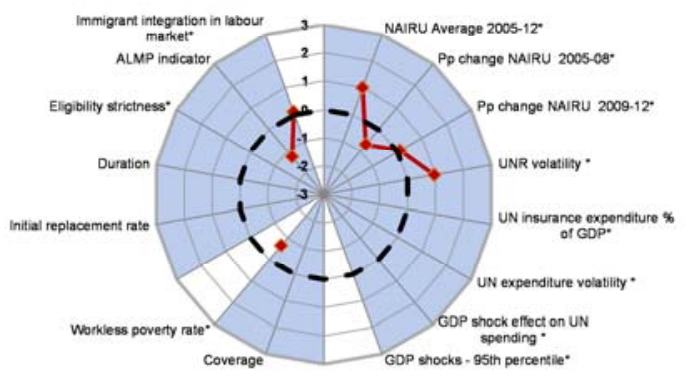

Adequacy

New Zealand

Policy levers

Sustainability

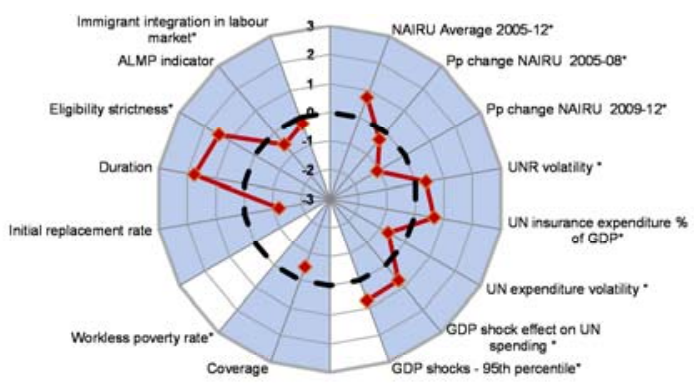

Adequacy
Luxembourg

Policy levers $\quad$ Sustainability

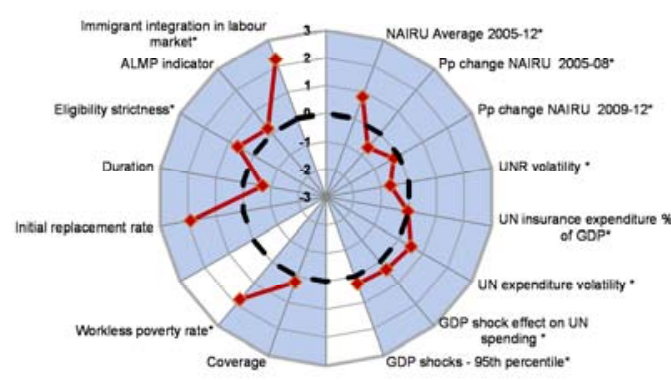

Adequacy

Netherlands

Policy levers

Sustainability

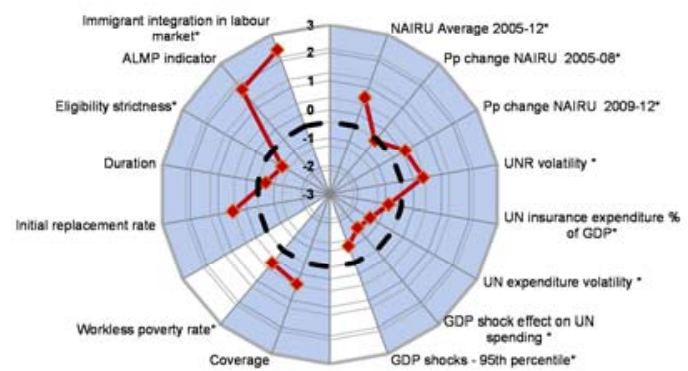

Adequacy

Norway

Policy levers

Sustainability

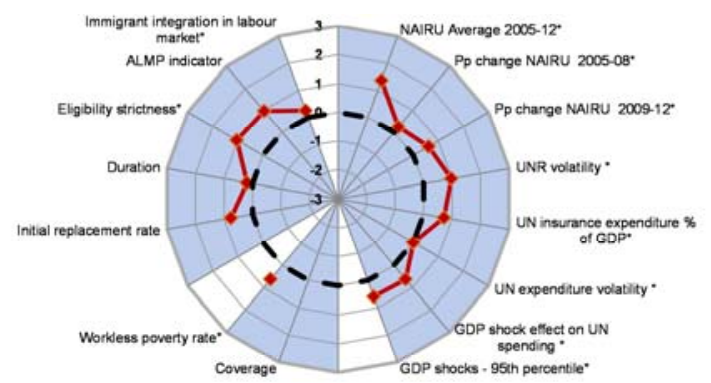

Adequacy 
COUNTRY PROFILES (cont'd)

Poland

Policy levers

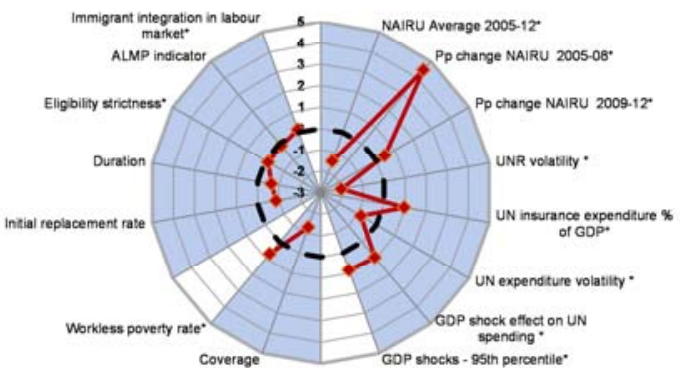

Adequacy

Slovak Republic

Policy levers

Sustainability

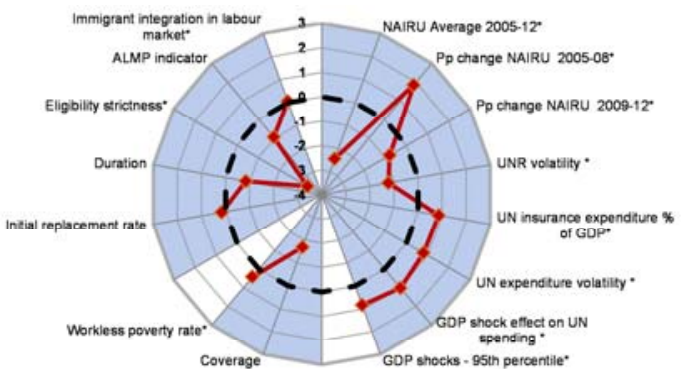

Adequacy

Spain

Policy levers

Sustainability

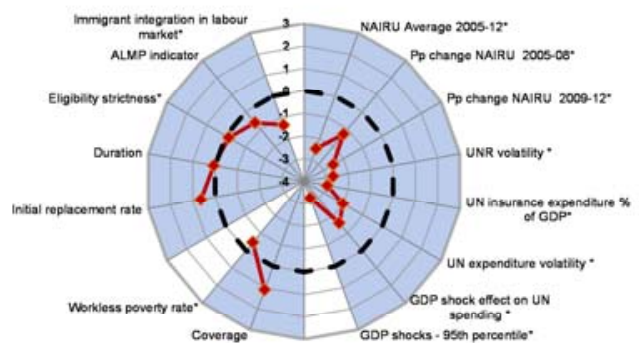

Adequacy
Portugal

Policy levers Sustainability

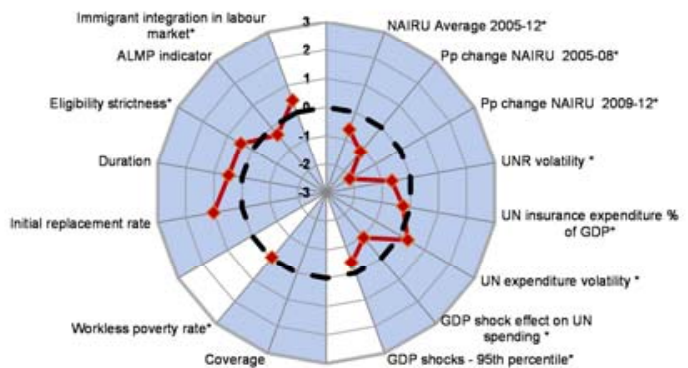

Adequacy

Slovenia

Policy levers $\quad$ Sustainability

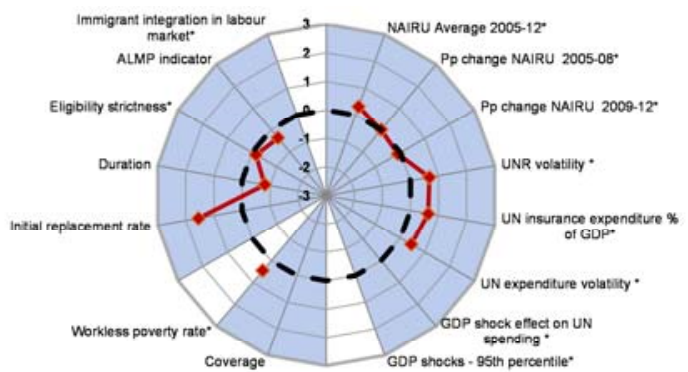

Adequacy

Sweden

$\begin{array}{ll}\text { Policy levers } & \text { Sustainability }\end{array}$

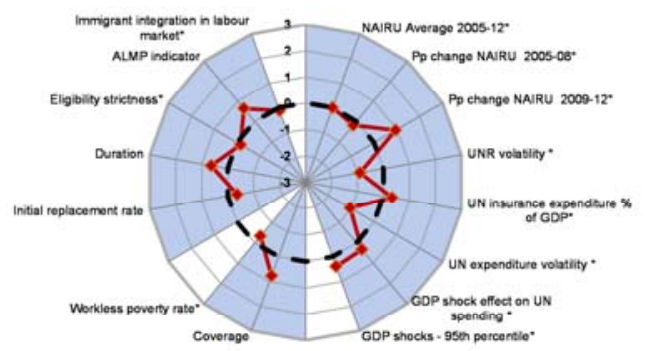

Adequacy 
COUNTRY PROFILES (cont'd)

Sustainability

Policy levers

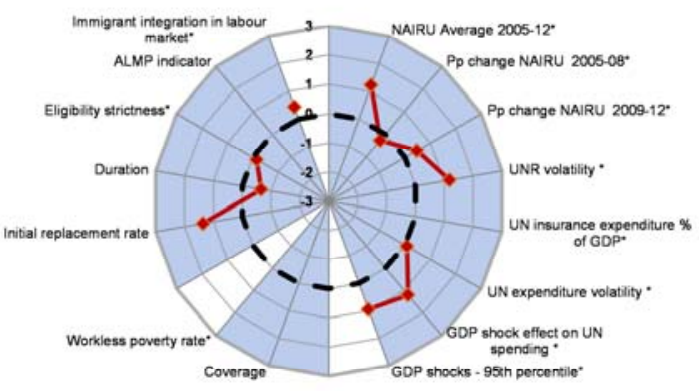

Adequacy

\section{United Kingdom}

Policy levers

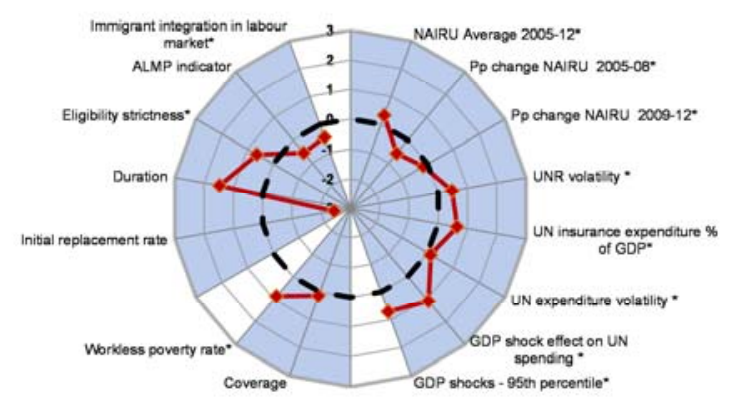

Adequacy
Turkey

Policy levers

Sustainability

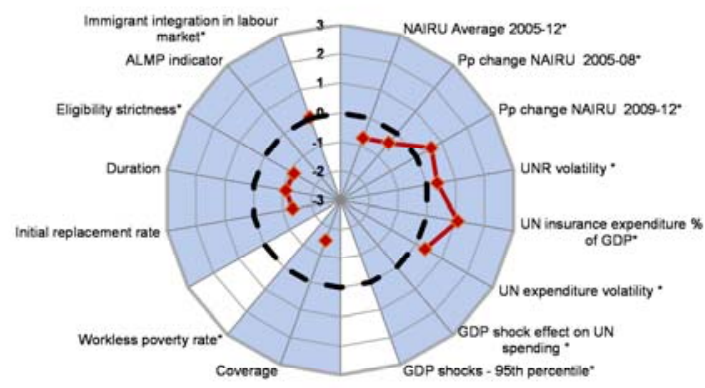

Adequacy

\section{United States}

Policy levers

Sustainability

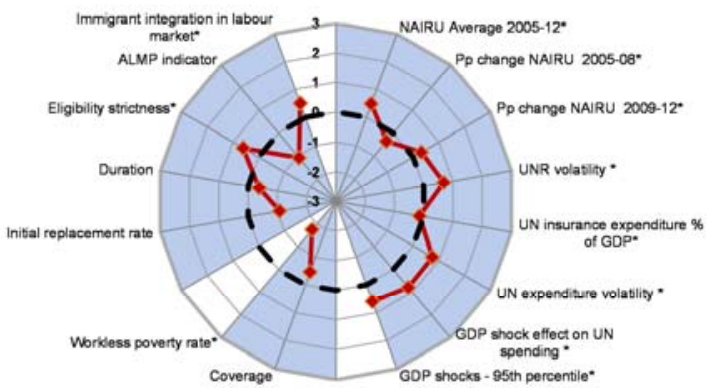

Adequacy

Note: The dotted line represents the OECD average, the solid line represents the country shown. Where the solid line falls inside the OECD average, the variable considered stands below the OECD average. For the "Policy options" indicators generosity is higher than the OECD average for observations above the dotted line. For the "Sustainability" and "Adequacy" indicators values are more favourable (e.g. NAIRU, volatility and poverty are lower and coverage is higher) the further the observation is removed from the centre of the diamond. The indicators are presented in units of standard deviation.

Legend:

Sustainability

NAIRU average 2005-12 = Average of structural unemployment rate

Pp change NAIRU 2005-08 = Change in percentage points between2005-08

Pp change NAIRU 2009-12 = Change in percentage points 2009-12

UNR volatility $=$ Standard deviation of the unemployment rate $(2000-12)$

UN insurance expenditure \% of GDP = Unemployment insurance benefits as \% of GDP (2011)

UN expenditure volatility = Standard deviation of UN insurance expenditure as \% of GDP (1990-2012)

GDP shock effect on UN spending = Unemployment insurance benefits in \% of total wages, median projection 2050

GDP shock $-95^{\text {th }}$ percentile $=$ Unemployment insurance benefits in $\%$ of total wages, the $95^{\text {th }}$ percentile projection 2050
Adequacy

Coverage $=$ Share of the unemployed entitled to unemployment benefits (200708)

Workless poverty rate $=\%$ of workless individuals with income below $50 \%$ of Policy options the median (2010)

Initial replacement rate $=$ Initial replacement rate in $\%$ of previous wage for an average of different family types and earnings

Duration $=$ Benefit duration in years (2011)

Eligibility strictness $=$ Months of work, membership or equivalent earnings to gain eligibility to UI (2011)

ALMP indicator = ALMP expenditure per unemployed in $\%$ of GDP per capita (2010)

Immigrant integration in labour market =Immigrant unemployment controlled for skills and country of origin, inverted 
ECO/WKP(2014)27

\section{APPENDIX A3 - DATA USED FOR THE PRINCIPAL COMPONENT ANALYSIS AND TABLE 2}

\section{Initial (first year) unemployment benefit replacement rate:}

Definition: Average unemployment benefit replacement rate during the first year of unemployment across two income situations (100\% and $67 \%$ of APW earnings in the years to 1999 , AW thereafter) and three family situations (single, with dependent spouse, with spouse in work).

Source: OECD, Benefits and Wages Database.

Data adjustments: original data are available only for odd years. Data for even years are obtained by linear interpolation.

\section{Labour tax wedge:}

Definition: tax wedge between the labour cost to the employer and the corresponding net take-home pay of the employee for a single-earner couple with two children earning $100 \%$ of APW earnings. The tax wedge expresses the sum of personal income tax and all social security contributions as a percentage of total labour cost.

Source: OECD, Taxing Wages.

Netherlands: unlike other years, in 2002 and 2003 APW earnings are just above the threshold beyond which employers and employees do no longer have to contribute to the national health insurance plan (private medical insurance is typically provided instead), thereby inducing a temporary decline in the tax wedge; this issue is addressed by replacing the 2002 and 2003 observations by data obtained from linear interpolations between the 2001 and 2004 observations.

\section{Employment Protection Legislation (EPL):}

Definition: OECD summary indicator of the stringency of Employment Protection Legislation for workers on permanent contracts (see Venn (2009) for details).

Source: OECD Employment Database, OECD Employment Outlook 2013, Venn, D. (2009), "Legislation, Collective Bargaining and Enforcement: Updating the OECD Employment Protection Indicators", OECD Social, Employment and Migration Working Papers, No. 89, OECD Publishing. doi: $10.1787 / 223334316804$

\section{Product Market Regulation (PMR):}

Definition: The indicators of product market regulation (PMR) are economy-wide indicators of policy regimes in OECD countries and have been estimated for 1998, 2003 and around 2008 for 30 OECD countries and for around 2008 for another 4 OECD countries (Chile, Estonia, Israel and Slovenia) as well as for Brazil, China, India, Indonesia, Russia and South Africa. These indicators summarise a wide array of different regulatory provisions across countries.

Source: OECD, Product Market Regulation Database, www.oecd.org/economy/pmr. 


\section{Degree of corporatism:}

Definition: indicator of the degree of centralisation/co-ordination of the wage bargaining processes, which takes values 1 for decentralised and uncoordinated processes, and 2 and 3 for intermediate and high centralisation/co-ordination.

Source: OECD, Employment Outlook 2004 and OECD, Employment Outlook 2012

Data adjustments: original data are five-year averages and classify countries in each period along a 0-5 scale from least to most "corporatist" countries. In the present paper, annual data have been reconstructed based on various sources on the timing of past changes in centralisation and/or co-ordination of wage bargaining. Furthermore, the indicator has been rescaled along a 1-3 scale. In this process, it has been assumed that wage bargaining in France predominantly occurs at the intermediate level, while original data describe it as a mix of firm-level and industry-level bargaining. For other countries, values 1, 2 and 3 correspond to values $1-2,3$ and $4-5$ in the original dataset, respectively.

\section{Union density:}

Definition: trade union density rate, i.e. the share of workers affiliated to a trade union, in \%.

Source: OECD Employment Database.

Data adjustments: data for missing years are obtained by linear interpolation.

\section{Union coverage:}

Definition: collective bargaining coverage rate, i.e. the share of workers covered by a collective agreement, in $\%$.

Source: OECD Employment Database.

\section{Public expenditures on active labour market policies (ALMPs):}

Definition: public expenditures on active labour market programmes per unemployed worker as a share of GDP per capita (or public expenditures on active labour market programmes as a share of GDP, depending on econometric specifications), in \%. The five main categories use in the disaggregated analysis are defined as follows:

1. Public employment services (PES) and administration: placement, counselling and vocational guidance, job-search courses, assistance with displacement costs, administration of unemployment benefits, all other administration costs of labour market agencies including running labour market programmes.

2. Labour market training: training for unemployed adults and those at risk, training for employed adults (special training programmes for youth and disabled are excluded).

3. Youth measures: special programmes concerning measures for unemployed and disadvantaged youth, support of apprenticeship and related forms of general youth training.

4. Subsidized employment: targeted measures to promote or provide employment for the unemployed and other priority groups (but not youth and the disabled).

5. Measures for the disabled: special programmes concerning vocational rehabilitation and work for the disabled.

Source: Based on the OECD Social Expenditure Database. 


\section{WORKING PAPERS}

The full series of Economics Department Working Papers can be consulted at www.oecd.org/eco/workingpapers

1130. Vulnerability of social institutions: Lessons from the recent crisis and historical episodes (July 2014) by Falilou Fall, Mauro Pisu, Jon Pareliussen and Debbie Bloch

1129. An update of the OECD international trade equations

(June 2014) by Myriam Morin and Cyrille Schwellnus

1128. What explains the volume and composition of trade? Industrial evidence from a panel of countries

(June 2014) by Asa Johansson, Przemyslaw Kowalski, Eduardo Olaberria and Dario Pellegrino

1127. Do resources flow to patenting firms: cross-country evidence from firm level data

(June 2014) by Dan Andrews, Chiara Criscuolo and Carlo Menon

1126. Macroprudential policy tools in Norway: Strengthening financial system resilience

(June 2014) by Yosuke Jin, Patrick Lenain and Paul O'Brien

1125. Strengthening competition in Poland

(June 2014) by Balász Égert and Antoine Goujard

1124. Making the labour market work better in Poland

(June 2014) by Hervé Boulhol

1123. Enhancing competition and the business environment in Hungary

(June 2014) by Alvaro Pina

1122. Tackling labour mismatches and promoting mobility in Hungary

(June 2014) by Stéphane Sorbe

1121. Local public finances and municipal reform in Finland

(June 2014) by Christophe André and Clara Garcia

1120. The economic consequences of ageing: the case of Finland

(June 2014) by Christine de la Maisonneuve, Christophe André, Clara Garcia and Vincent Koen

1119. Making the most of skills in Denmark

(June 2014) by Stéphanie Jamet and Vincent Koen

1118. Trade specialisation and policies to foster competition and innovation in Denmark (June 2014) by Müge Adalet McGowan

1117. Policies for making the Chilean labour market more inclusive

(June 2014) by Aida Caldera Sanchez

1116. Spillover effects from exiting highly expansionary monetary policies

(May 2014) by Łukasz Rawdanowicz, Romain Bouis, Jérôme Brezillon, Ane Kathrine Christensen and Kei-Ichiro Inaba 
1115. Economic policies and microeconomic stability: A literature review and some empirics (April 2014) by Paula Garda and Volker Ziemann

1114. How to improve Israel's health-care system (April 2014) by Philip Hemmings

1113. How to improve taxes and transfers in Israel (April 2014) by Philip Hemmings

1112. New evidence on the determinants of industrial specialisation (April 2014) by Asa Johansson and Eduardo Olaberria

1111. Economic growth from the household perspective: GDP and income distribution developments across OECD countries

(April 2014) by Orsetta Causa, Sonia Araujo, Agnès Cavaciuti, Nicolas Ruiz and Zuzana Smidova

1110. Would a growth slowdown in emerging markets spill over to high-income countries? A quantitative assessment (April 2014) By Patrice Ollivaud, Elena Rusticelli and Cyrille Schwellnus

1109. Short-term indicator models for quarterly GDP growth in the BRIICS: A small-scale bridge model approach

(April 2014) by Thomas Chalaux and Cyrille Schwellnus

1108. The prudential regulation of financial institutions: why regulatory responses to the crisis might not prove sufficient

(March 2014) by William R. White

1107. OECD forecasts during and after the financial crisis: a post mortem

(March 2014) by Nigel Pain, Christine Lewis, Thai-Thanh Dang, Yosuke Jin and

Pete Richardson

1106. Fairly sharing the social impact of the crisis in Greece

(January 2014) by Vassiliki Koutsogeorgopoulou, Manos Matsaganis, Chrysa Leventi and Jan-David Schneider

1105. Dividing the pie in Brazil: income distribution, social policies and the new middle class (January 2014) by Jens M. Arnold and João Jalles

1104. New indicators of competition law and policy in 2013 for OECD and non-OECD countries (December 2013) by Enrico Alemani, Caroline Klein, Isabell Koske, Cristiana Vitale and Isabelle Wanner

1103. The effect of government debt, external debt and their interaction on OECD interest rates (December 2013) by David Turner and Francesca Spinelli

1102. The state of the banking sector in Europe (December 2013) by Dirk Schoenmaker and Toon Peek 